University of Michigan Law School University of Michigan Law School Scholarship Repository

1977

\title{
Federal Taxation of the Assignment of Life Insurance
}

Douglas A. Kahn

University of Michigan Law School, dougkahn@umich.edu

Lawrence W. Waggoner

University of Michigan Law School, waggoner@umich.edu

Available at: https://repository.law.umich.edu/articles/385

Follow this and additional works at: https://repository.law.umich.edu/articles

Part of the Estates and Trusts Commons, Insurance Law Commons, Taxation-Federal Commons, and the Taxation-Federal Estate and Gift Commons

\section{Recommended Citation}

Kahn, Douglas A. "Federal Taxation of the Assignment of Life Insurance." L. W. Waggoner, co-author. Duke L. J. 1977 (1977): $941-82$.

This Article is brought to you for free and open access by the Faculty Scholarship at University of Michigan Law School Scholarship Repository. It has been accepted for inclusion in Articles by an authorized administrator of University of Michigan Law School Scholarship Repository. For more information, please contact mlaw.repository@umich.edu. 


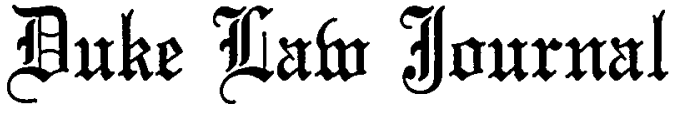

VOLUME 1977 DECEMBER Number 5

\section{FEDERAL TAXATION OF THE ASSIGNMENT OF LIFE INSURANCE}

\author{
DOUGlas A. KaHN* AND LAWRENCE W. WAGGONER**
}

I. LIFE INSURANCE AND ITS ECONOMIC COMPONENTS ................ 943

II. THE GENERAL FRAMEWORK OF THE TAXATION OF LIFE

INSURANCE ................................................... 946

A. Income Taxation of Life Insurance ......................... 946

1. Exclusion of Proceeds from Gross Income ............. 946

2. Appreciation in Reserve ............................ 947

B. Estate Taxation of Life Insurance ......................... 948

C. Gift Taxation of Life Insurance .......................... 949

1. Annual Exclusion .................................. 950

2. Importance of Qualifying for the Annual Exclusion.... 951

III. ASSIGNMENT OF OWNERSHIP MORE THAN THREE YeARS PRIOR TO THE INSURED's DEATH ....................................... 954

A. Payment of Premiums by the Insured ..................... 955

B. The Constructive Transfer Principle and its Proper Limits. 956

C. The Purpose and Function of Section 2035 ................ 960

IV. ASSIGNMENT OF OWNERSHIP WITHIN THREE YEARS OF DEATH ... 962

A. No Post-Assignment Premiums Become Due............... 963

B. Post-Assignment Premiums Become Due But Are

Not Paid, Resulting in a Lapse of the Policy................ 964

C. Post-Assignment Premiums Become Due and Are

Paid by the Insured ........................................ 967

D. Post-Assignment Premiums Paid by the Assignee .......... 968

1. Judicial Consideration of the Question ................ 968

2. Return of the Percentage of Premiums Test ............ 970

3. The Proposed Treatment .............................. 975

(a) The equity reserve component .................. 975

(b) The term insurance coverage and the right of continuation components ........................ 977

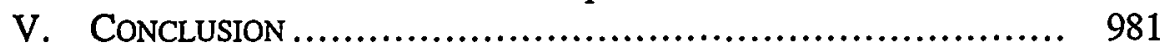

* Professor of Law, University of Michigan. B.A. 1955, University of North Carolina; J.D. 1958, George Washington University.

** Professor of Law, University of Michigan. B.B.A. 1960, University of Cincinnati; J.D. 
The most litigated estate tax issue concerning life insurance ${ }^{1}$ is whether the proceeds should be included in the insured's gross estate. This question usually is governed by section 2042 of the Internal Revenue Code of 1954, the estate tax provision directed specifically at life insurance. While the Tax Reform Act of 1976 wrought enormous changes in many areas of estate taxation, Congress did not change section 2042. Thus the several unresolved questions concerning the interpretation of that section remain unsettled. ${ }^{2}$

But the question of the includability of life insurance proceeds in the gross estate of the insured is not always governed by section 2042 . It sometimes turns on one of the other sections of the Code, notably section 2035. This Article will deal with the treatment under section 2035 of various types of transactions concerning life insurance. Prior to the 1976 amendments, section 2035 required the inclusion of the value of property of all types, including life insurance, given away by the decedent within three years of his death if the transfer was "in contemplation of his death." This test required a determination of the decedent's motives in making the gift. ${ }^{3}$ The 1976 Act removed the necessity of making that determination by substituting an automatic rule requiring the includability of gifts made by the decedent within three years of his death regardless of motive. ${ }^{4}$ Thus one of

1963, University of Michigan; D.Phil. 1966, Oxford University.

Portions of this Article are drawn from the authors' book FEDERAL TAXATION OF GIFTs, TRusts AND EstaTes (Little, Brown \& Co. 1977).

The authors wish to express their appreciation to Mr. Michael Alan Ellis for his many useful contributions, and to thank Professors Pamela B. Gann and John Weistart for their valuable criticisms and comments of a draft of this Article.

1. The terminology used in connection with life insurance may be unfamiliar. The "insurer" is the company which issues the insurance policy; the "insured" is the person whose life is insured by the policy; the "beneficiary" is the person to whom the proceeds of the insurance are payable; and the "policyholder" is the owner of the policy-that is, the person who possesses the economic rights in and power over the policy (for example, the right to surrender the policy for cash, borrow against the policy, name the beneficiary, and the like). Note that the policyholder need not also be the insured.

2. See, e.g., Estate of Connelly v. United States, 551 F.2d 545 (3d Cir. 1977) (power to elect settlement option, and thus to affect proceeds' payment schedule, the exercise of which required consent of employer and insurer, did not constitute an "incident of ownership" under $\S$ 2042); Terriberry v. United States, 517 F.2d 286 (5th Cir. 1975), cert. denied, 424 U.S. 977 (1976) (power, as a trustee, to elect a settlement option constituted an "incident of ownership" even though insured's wife could terminate his power at will); Rose v. United States, 511 F.2d 259 (5th Cir. 1975) (power, as a trustee, to alter time and manner of enjoyment of policy held in trust constituted an "incident of ownership"); Estate of Skifter v. Commissioner, 468 F.2d 699 (2d Cir. 1972) (broad fiduciary powers conveyed to, and not retained by, an insured did not constitute an "incident of ownership"). See also Rev. Rul. 76-261, 1976-2 C.B. 276 (addressing the same issue presented in Skifter but ruling to the contrary).

3. See, e.g., Berman v. United States, 487 F.2d 70 (5th Cir. 1973) (where such a determination of subjective intent was made).

4. I.R.C. § 2035(a), as amended by Tax Reform Act of 1976, Pub. L. No. 94-455, § 2001(a)(5), 90 Stat. 1848. 
the problems concerning the application of section 2035 to transfers with respect to life insurance has been eliminated. A number of problems remain, however. One interesting and currently controversial problem is what amount should be included in the insured's gross estate if he gives away a policy within three years of his death but the assignee, not the insured, pays the post-assignment premiums that become due. ${ }^{5}$ The 1976 Act did not address this matter, and it generally has been neglected by tax commentators. This Article will explore that issue, along with others arising from the assignment of life insurance, and suggest some solutions. Before the tax treatment of the assignment of life insurance can be analyzed, the economic components of a life insurance policy need to be identified with some precision.

\section{LIFE INSURANCE AND ITS ECONOMIC COMPONENTS}

The basic element of life insurance is risk coverage-coverage against the risk that the insured will die during a stated period. Life insurance is designed to provide compensation for the financial loss that the beneficiaries of a policy would otherwise suffer as a consequence of the insured's death prior to the expiration of his or her life expectancy. The cost of this risk coverage (the pure insurance cost of the policy) is determined roughly in the manner indicated by the following example. John Jones of $x$ age and in good health wishes to acquire $\$ 1,000$ of life insurance for a one-year period. The insurance company's actuarial tables indicate that $1 \%$ of persons of $x$ age will die during that year. Thus, a premium charge of approximately $1 \%$ ( $\$ 10)$ will cover the risk of death for that year. In addition, the company has management and selling expenses which will be passed on to the policyholders, and so Jones's premium will be somewhat greater than $\$ 10$. If the insurer is a profit-making stock company, the premium may include an allowance for the company's profit. If the insurer is instead a mutual company ${ }^{6}$ the company will charge a larger premium than it reasonably expects to need and at the end of each year will return the excess amount over its actual needs to the policyholders as a so-called "dividend."7 Policies which pay such "dividends" are called "participating insurance." While participating insurance is commonly offered by mutual companies, it is also offered by some stock companies.

The purchase of pure insurance coverage for a stated term is called

5. See, e.g., Estate of Silverman v. Commissioner, 521 F.2d 574 ( $2 \mathrm{~d}$ Cir. 1975). See also text accompanying notes $98-122$ infra, where this issue is examined.

6. A mutual company has no stockholders and passes its earnings on to its policyholders and to certain beneficiaries of matured policies.

7. See note 17 infra. 
"term insurance." In the case of Mr. Jones, the annual premium of his $\$ 1,000$ one year term policy was $\$ 10$ plus. If Jones should wish to continue that coverage for an additional year, the premium cost will be higher, since the percentage of persons $x+1$ years of age who will die during the year is greater than the percentage of persons only $x$ years of age who will die during the year. Thus, each year the premium cost of the term insurance will increase. Term insurance typically is purchased for a specific term such as five years, with an automatic right of the owner to renew at the end of each term; the premium cost of the insurance, however, will increase as the insured ages. If the insured attains an advanced age, the size of the premium will become prohibitively high.

If Jones wishes to have insurance for a period in excess of one year but seeks to avoid this steady increase in the annual premium, he can purchase life insurance for a term consisting of a substantial number of years and pay the same amount of premium each year for a decreasing amount of insurance. The annual premium payments will therefore remain constant, but every few years the amount of insurance coverage will be reduced. This variation of term insurance is called "declining term life insurance."

A second type of life insurance is ordinary life, frequently called "straight life" or "whole life," insurance. Ordinary life insurance combines the purchase of pure risk coverage with an investment. Part of the premium is charged to the pure insurance coverage of the policy (including the company's expenses) and part of the premium is treated as an investment by the policyholder with the insurer; this investment is referred to as the policyholder's "reserve" (or "terminal reserve") in the policy. The reserve is an equity interest of the policyholder, and typically it appreciates in value each year at a fixed rate of increase established in the insurance contract. ${ }^{8}$

In the first few years of an ordinary life policy, the policyholder obtains little or no reserve in the policy because most of the early premiums are used to pay the company's expenses, including selling commissions. After this initial period, the reserve increases each year, both because of appreciation in the established reserve and because of the policyholder's payment of additional premiums. Since the amount payable at death typically is a fixed dollar figure, the amount of insurance risk coverage purchased by the policyholder is the difference between the amount payable at death and the policyholder's reserve. Since the reserve, representing the policyholder's

8. A variation of ordinary life is "variable life insurance." It is similar to ordinary life insurance, except that it may not guarantee a specified return. The policyholder's reserve and the death benefit may therefore vary from year to year according to the relative success or failure of the insurer's investment program; a guaranteed minimum death benefit is, however, frequently provided. Variable life insurance is a modern creation and has not yet become as popular as ordinary life insurance. 
equity, increases each year, the policyholder actually purchases less insurance each year, resulting in premiums which remain at a constant level. In effect, the policyholder has combined an investment program providing a secure but relatively low rate of return with declining term life insurance coverage.

A policyholder may borrow from the insurer against his reserve or he can surrender the policy for its cash value. Because of administrative costs, the amount that can be realized by surrendering the policy or by borrowing on it is slightly less than the policyholder's reserve. The amount realizable on a surrender of the policy is called the "cash surrender value"; this value at a given date typically can be determined from tables included in the policy itself. After approximately five years from the date a policy is taken out, the cash surrender value usually will be only slightly less than the policyholder's reserve and can be used as an approximation of the reserve for planning purposes. Upon request, the insurer will provide the policyholder with a statement of the current value of the reserve.

On the death of the insured, the proceeds of the policy are payable according to the method of settlement elected by the owner of the policy or by the beneficiary. The various methods available for settling the proceeds of a matured life insurance policy are referred to as "settlement options." These settlement options, typically selected by the beneficiary after the insured's death, permit an election either to have the insurance proceeds paid to the beneficiary in one lump sum or to have the insurance company retain the proceeds and pay it out under one of a variety of plans. ${ }^{9}$ Froin the above description of the types of life insurance policies available and their various features, three economic components of life insurance emerge: (1) the term insurance coverage component (coverage agaimst the risk of the insured's death within the period covered by the last premium paid); (2) the

9. Some of the most common options are:

(a) Interest only or deposit option-interest is paid currently to the beneficiary, who is empowered to change to some other settlement option (including a lump sum payment); some policies require the beneficiary to make such a change of election within some stated period of time after the insured's death, but most policies permit the change of election to be made at any time. The purpose of the deposit option is to provide interest on proceeds left with the insurer while the beneficiary decides which settlement to elect.

(b) Fixed period option - the proceeds are paid out in installments of no less than a specified amount over a fixed period of time, and if the policy earns more than a minimum guaranteed interest for any installment period, the amount of installment payment made to the beneficiary for that period will be increased accordingly.

(c) Fixed amount option - the proceeds are payable in a specified minimum number of installments of a fixed amount; if the policy earns more than the guaranteed minimum income, the number of payments is increased but the amount of each installment payment remains constant.

(d) Straight life annuity-a periodic payment of a fixed dollar amount to be made during the life of the beneficiary. Recently, some life insurance companies have offered a variation of the straight life annuity called the "variable life annuity," under which the periodic payments will vary in amount according to the success of the company's investments. 
right of continuation component (the right to continue having insurance coverage at a fixed price, regardless of the insured's health, beyond the period covered by the last premium); and (3) the equity of terminal reserve component. Of course, not all life insurance policies are comprised of all three components. Nevertheless, it is important to keep these components in mind for they will be crucial to the analysis that will be developed concerning the proper tax treatment of assignments of life insurance policies. To set the stage for this analysis, a description of the general framework of the taxation of life insurance should first be set forth.

\section{The General Framework of the TAXation of Life Insurance}

\section{A. Income Taxation of Life Insurance.}

1. Exclusion of Proceeds from Gross Income. In general, section 101 of the Internal Revenue Code excludes life insurance proceeds from the beneficiary's gross income. ${ }^{10}$ When the proceeds are payable in one lump sum, the exclusion provided by section 101 is straightforward. When, however, the beneficiary or the owner of the policy selects one of the other settlement options that provides for the retention of the proceeds by the insurer, the operation of the exclusion becomes somewhat complicated. Of

(e) Self and survivor annuity - an annuity of a specified amount paid periodically for the life of the primary beneficiary and on his or her death, survived by a named secondary beneficiary, an annuity of a specified amount (which may be smaller than the primary beneficiary's annuity) will be paid to the secondary beneficiary for life.

(f) Joint and survivor annuity-an annuity for the joint lives of two beneficiaries and for the life of the survivor. (The term "joint and survivor annuity" is sometimes used to describe a self and survivor annuity option.)

(g) Annuity with a refund or guaranteed payment-a refund feature of an annuity provides that if less than a specified amount has been paid to the beneficiary or beneficiaries at the time of the death of the last annuitant, the difference is payable in one lump sum to some named person or persons. Another variation of this is an annuity option with a guaranteed payment feature which provides that payments will be made for no less than a specified period of time, regardless of when the beneficiaries die.

Although settlement options are not as flexible a vehicle as a trust, they are not entirely inflexible. For example, a fixed period option may provide for installment payments for part of the option period larger than other payments, although the size of the payments typically must be fixed at the time that the election is made.

10. One important exception to the general rule of excluding lump sum insurance payments from gross income is the "transferee for value" rule. If the person owning a life insurance policy on the death of the insured had acquired it for valuable consideration from someone other than the insurer, the amount of proceeds excluded from gross income is limited to the consideration and premiums paid by such person. I.R.C. $\$ 101(a)(2)$. This rule does not apply to a person who initially purchased the policy from the insurer; nor does it apply to a transferee of a policy who received it without consideration, provided that the transferor was not himself a transferee for value (or himself a transferee of a transferee for value). See Treas. Reg. $\S \S 1.101-$ 1(b)(3)(iii), 1.101-1(b)(5) Ex. (4) (1957). Even if a tranisferee acquired the policy for valuable consideration, the transferee for value rule is not applicable if the transferee were the insured, a partner of the insured, a partnership in which the insured is a partner or a corporation in which the insured is a shareholder or officer. See I.R.C. $\$ 101(a)(2)(B)$. 
course, interest paid to a beneficiary on proceeds held by the insurer is included in the beneficiary's gross income. ${ }^{11}$ In the case of installment payments made to a beneficiary, ${ }^{12}$ the interest element of the payment is included in the beneficiary's gross income; the portion of the installment payment which is characterized as principal, however, is excluded. ${ }^{13}$ Typically, the "principal" portion of an installment payment is a percentage of the face amount of the insurance. The same proportion of each installment payment is excluded irrespective of whether the aggregate of the prior payments of principal exceeds the face amount of the insurance. ${ }^{14}$ Moreover, when life insurance proceeds are payable in installments to a surviving spouse of the insured, section 101(d)(1)(B) excludes up to $\$ 1,000$ of the interest portion of such installments paid in a taxable year from the gross income of the surviving spouse. This exclusion does not apply, however, to interest paid on a deposit or "interest only" 15 option. ${ }^{16}$

2. Appreciation in Reserve. A policyholder's reserve or equity interest in an ordinary life insurance policy appreciates each year. 'To the extent that this appreciation is not attributable to the policyholder's payment of additional premiums, it constitutes "earnings" from the policyholder's investment; these "earnings," however, are not taxed to the policyholder. ${ }^{17}$

11. See I.R.C. § 101(c).

12. Typically, such payments are made under an annuity, fixed amount or fixed period option. See note 9 supra.

13. I.R.C. $\S \S 101(d)(1),(d)(1)(A)$.

14. This occurs where a beneficiary of an annuity option outlives his life expectancy.

15. See note 9 supra.

16. See Treas. Reg. $\S \S 1.101-3,1.101-4$ (h) (1960), T.D. $6577,1961-2$ C.B. 17, 18-19.

17. Note that if a policyholder owns a participating life insurance policy, the so-called "dividend" paid by the insurer to the policyholder each year is in fact a return of part of the premiums previously paid by the policyholder, and so such "dividends" are not included in the policyholder's gross income. See 1 J. MERTENS, THE LAW OF FEDERAL INCOME TAXATION $\$ 7.08$ (rev. ed. 1974) (citing Treas. Reg. § 1.72-11(b) (1960)); cf. Rev. Rul. 64-258, 1964-2 C.B. 134 (holding that such payments do not constitute an inurement of net earnings to the policyholders so that a tax-exempt organization's distribution to its members of the "dividends" it received on policies insuring the life of its members did not disqualify the organization of its tax-exempt status under I.R.C. $\$ 501(\mathrm{c})(10)$ ). Even "dividends" remitted on paid-up policies-policies for which no further premium payments are due-are excluded from gross income because such dividends are in essence a reduction of premiums paid in prior years. See 1 J. MERTENS, supra, $\S 7.08$, at 18 n.35. If, however, the policyholder does not withdraw the dividends from the insurance company but instead leaves them on deposit with the insurer to earn interest, the interest credited to the accumulated dividends is included in the poiicyholder's gross incomesuch interest is no different from interest credited to a savings account deposit. Id.

Note also that if a policyholder sells his insurance policy to a third party, he will recognize a gain on the sale only if the amount he realized thereon exceeds his basis in the policy. Since all of the premiums previously paid by the policyholder (less the "dividends" he received) are included in his basis, the amount realized usually will not exceed the seller's basis. The reason that the amount realized on a surrender of the policy often will be less than the policyholder's basis is that the policyholder is permitted to include in his basis the portion of his premiums that 
The rationale given for not taxing such appreciation to the policyholder is that the income has not been "realized," or even "constructively received," in the tax sense. ${ }^{18}$ Moreover, even though the face amount of the proceeds payable to the beneficiary upon the death of the insured includes this appreciation in the value of the policyholder's equity, such proceeds generally are excluded from the gross income of the beneficiary by section $101 .^{19}$

\section{B. Estate Taxation of Life Insurance.}

In determining how life insurance should be treated for transfer tax purposes, one should keep in mind that the proper'and widely accepted view of life insurance is that upon the death of the insured, the policyholder's equity interest in the policy passes to the named beneficiaries along with a payment by the insurer of an amount representing the proceeds of the risk coverage element of the policy. ${ }^{20}$ Thus, the payment that the beneficiaries receive of the face amount of a policy is comprised of two separate elements: the equity interest of the policyholder and a death benefit payment. This view of insurance conforms with the actuarial justification for the size of premiums charged for a policy which is that the premiums are sufficient only to purchase risk coverage for the difference between the face amount of the policy and the policyholder's equity therein.

When the proceeds of a life insurance policy are received by the insured's executor, section 2042(1) of the Code mandates that they be included in the gross estate of the insured. This explicit inclusion of life insurance proceeds payable to the insured's executor, while not free of ambiguity, has not been especially troublesome to apply. In general, the reference to the insured's "executor" means payable to or on behalf of the insured's estate. ${ }^{21}$

Where the named beneficiary of an insurance policy is someone other than the insured's executor, section 2042(2) requires the insurance proceeds to be included in the insured's gross estate if he possessed, at his death, any "incidents of ownership" in the policy. While the Code makes no attempt to define "incidents of ownership," the regulations make it clear that the term is not limited to actual dominion over the policy, but also includes a

was attributable to the purchase of the insurance coverage for a specified period; the policyholder's basis is not limited to the portion of the premium that constituted the policyholder's addition to his reserve.

18. See Theodore H. Cohen, 39 T.C. $1055,1062-64$ (1963).

19. It should be noted, however, that I.R.C. $₹ 101(a)(2)$ - the "transferee for value" provision discussed at note 10 supra - is an exception to this rule.

20. See, e.g., United States v. Bess, 357 U.S. 51, 59 (1958); Old Kent Bank \& Trust Co. v. United States, 430 F.2d 392, 395-96 (6th Cir. 1970).

21. See Treas. Reg. § 20.2042-1(b) (1960). 
lesser economic interest or benefit, such as the right to surrender or cancel the policy, change the named beneficiary, or pledge the policy for a loan. ${ }^{22}$

An alternative approach to inclusion in cases where someone other than the insured's executor is the beneficiary was employed prior to the adoption of the 1954 Code. ${ }^{23}$ During the twelve-year period ending with the adoption of the 1954 Code, in cases where the insured owned no incidents of ownership in the policy at the time of his death, a fraction of the proceeds (equal to the proportion of premiums paid by the insured to all premiums paid on the policy) was included. ${ }^{24}$ In adopting the 1954 Code, Congress eliminated this premium payment test in order to treat life insurance on a par with other property. The House Ways and Means Committee reasoned that "[n]o other property is subject to estate tax where the decedent initially purchased it and then long before his death gave away all rights to the property" and to discriminate against life insurance in this regard was not justified. ${ }^{25}$ The legislature's action, however, was sharply criticized by some congressmen ${ }^{26}$ and tax commentators. ${ }^{27}$ The merits of the premium payment test will be discussed later in this Article, ${ }^{28}$ and we shall demonstrate that there is no justifiable policy for adopting that rule. The premium payment test is particularly significant because the Tax Court's treatment (for estate tax purposes) of life insurance proceeds where the insured had assigned the policy within three years of his death and where the assignee paid the premiums thereafter may well have been derived from a residual adherence to the premium payment rationale.

\section{Gift Taxation of Life Insurance.}

There is no statutory gift tax provision expressly dealing with the transfer of a life insurance policy or the payment of its premiums, and so such transfers are dealt with under the general gift tax provisions applicable to all types of transfers. ${ }^{29}$ The regulations do provide that if the insured

22. Treas. Reg. $\$ 20.2042-1$ (c)(2) (1958). The term also includes "a reversionary interest in the policy or its proceeds, whether arising by the express terms of the policy or other instrument or by operation of law, but only if the value of the reversionary interest . . . exceeded 5 percent of the value of the policy." Treas. Reg. $\$ 20.2042-1$ (c)(3) (1958).

23. Int. Rev. Code of 1939 , ch. $3, \S 811(\mathrm{~g})(2), 53$ Stat. 1, 122, as amended by Revenue Act of $1942, \S 404,56$ Stat. $798,944$.

24. Id.

25. H.R. ReP. No. 1337, 83d Cong., 2d Sess. 91 (1954), reprinted in [1954] U.S. CodE Cong. \& AD. News 4017, 4118.

26. See id. B14, reprinted in [1954] U.S. CODE CONG. \& AD. NEws 4017, 4608 (minority views).

27. See, e.g., C.Lowndes, R. Kramer \& J. MCCord, Federal Estate and Gift TaXes $\S 13.4$ (3rd ed. 1974); 4 J. Rabin \& M. Johnson, Federal Income, GifT and Estate TAXATION $\S 61.04(3)$ (rev. perm. ed. 1977).

28. See text accompanying notes 105-07 infra.

29. See I.R.C. $\S \S 2511-2512$. 
irrevocably assigns an insurance policy to another, "[t]he insured has made a gift of the value of the policy" to the extent that the assignment exceeds the value of any consideration received by the insured..$^{30}$

The gift tax value of a gift of a life insurance policy is its replacement cost-the amount necessary to purchase a comparable policy from a company regularly engaged in the selling of insurance. ${ }^{31}$ The value of an insurance policy may not be readily ascertainable, such as when the gift is a policy that has been in effect for some time and upon which further premiums must be paid. In that event the value of the gift is obtained by combining the amount of the terminal reserve of the policy at the date of the gift and the proportionate part of the last premium paid before the date of the gift which covers the period extending beyond that date. ${ }^{32}$ If the donor continues to pay premiums after making a gift of the life insurance policy, he is deemed to have made an additional gift to the extent of each premium paid. ${ }^{33}$

1. Annual Exclusion. Note, however, that all or a portion of a gift of a life insurance policy may be excluded from gift tax. Section 2503(b) of the Code provides that a donor is entitled to an annual exclusion of $\$ 3,000$ for gifts, other than gifts of "future interests,"34 given to each donee. An outright gift of an insurance policy (as contrasted to a gift in trust) is treated as a gift of a present interest, even though the proceeds will not be collected until a future date. ${ }^{35}$ The annual exclusion can also apply to premium

30. Treas. Reg. $\$ 25.2511-1(\mathrm{~h})(8)$ (1958). No reason exists for limiting the tax to transfers made by the insured; a gift tax will be imposed on any donor of a life insurance policy, unless a section of the Code expressly provides otherwise.

31. Treas. Reg. \$ 25.2512-6(a) (1958).

32. Id. The following example is given by the regulations:

Example (4). A gift is made four months after the last premium due date of an ordinary life insurance policy issued nine years and four months prior to the gift thereof by the insured, who was 35 years of age at date of issue. The gross annual premium is $\$ 2,811$. The computation follows:

Terminal reserve at end of tenth year ..........................................\$14,601.00

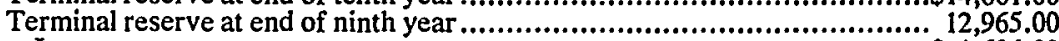

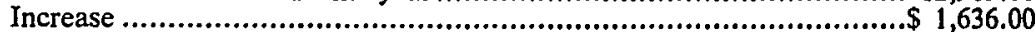

One-third of such increase (the gift having been made four months

following the last preceding premium due date), is ............................\$ 545.33

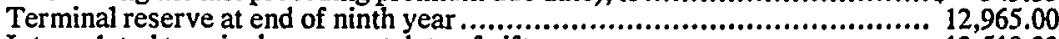

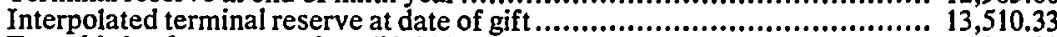

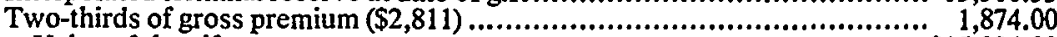

Value of the gift .............................................................\$15,384.33

33. See Treas. Reg. \& 25.2511-1(h)(8) (1958).

34. The term "future interest" has its own definition under the gift tax provisions and does not have the same meaning as it does under general property law. Any gift under which the donee's possession, use or enjoyment is postponed is a gift of a future interest. See Treas. Reg. $\S 25.2503-3$ (a) (1958).

35. In Rev. Rul. 55-408, 1955-1 C.B. 113, the Commissioner repudiated a suggestion made by the Tax Court in Nashville Trust Co., 2 T.C.M. (CCH) 992 (1943), that a gift of a policy before it had built up any cash surrender value was a gift of a future interest. See also Treas. Reg. $\$ 25.2503-3$ (a) (1958). It should be noted, however, that if the gift is subject to a limitation 
payments made by the donor in subsequent years. ${ }^{36}$ If a life insurance policy is assigned to a trustee, however, the gift of the policy and any subsequent premium paid by the donor likely will not qualify for the annual exclusion. ${ }^{37}$

2. Importance of Qualifying for the Annual Exclusion. The qualification of gifts of insurance policies and premium payments for the annual exclusion took on added importance as a consequence of the recent integration of estate and gift taxation by the Tax Reform Act of $1976 .{ }^{38}$ Congress took several steps to accomplish this integration. First, it provided the same tax rate schedule for all donative transfers (whether inter vivos or testamentary) made after 1976.39 Second, Congress provided that the "adjusted taxable gifts" made by a decedent are to be included in the decedent's estate tax base on his death, and that the estate tax payable on the estate tax base is to be reduced by any gift taxes paid or payable with respect to gifts made by the decedent after 1976. This means, in effect, that while the adjusted taxable gifts previously made by a decedent are not subject to an additional tax upon his death, ${ }^{40}$ such gifts do increase the rate of tax applicable to the decedent's taxable estate so that the amount of tax payable thereon will equal the amount that would have been payable at his death if the decedent had also owned at his death property having a value equal to his adjusted taxable gifts.

The "adjusted taxable gifts" of a decedent are the aggregate of the taxable gifts of the decedent which were made after 1976, other than gifts which are includable in the decedent's gross estate. ${ }^{41}$ Since the amount of a

which restricts the donee's right to reassign the policy, obtain its cash surrender value or borrow against its terminal reserve, then the donated property constitutes a future interest, and no annual exclusion can be claimed. See Ryerson v. United States, 312 U.S. 405, $408-09$ (1941); Skouras v. Commissioner, 188 F.2d 831 (2d Cir. 1951); John M. Smyth, 2 T.C.M. (CCH) 4 (1943).

36. See Rev. Rul. 76-490, 1976-2 C.B. 300; Rev. Rul. 55-408, 1955-1 C.B. 113.

37. See note 53 infra. If the donor is married and his spouse consents to split the donor's gifts between them under section 2513 , the $\$ 3,000$ available annual exclusion for the donor's gifts to a third party (someone other than the donor's spouse) may be doubled to $\$ 6,000$. If a gift is made to the donor's spouse, only $\$ 3,000$ can be excluded, but the balance of the gift may qualify for a marital deduction. The amount of gifts to a spouse which can qualify for a marital deduction was liberalized by the Tax Reform Act of 1976. In general, a deduction was allowed for one-half of the qualified gifts made to a spouse prior to 1977. After 1976, the first $\$ 100,000$ of value of qualified taxable gifts is deductible; the next $\$ 100,000$ of value of such gifts is not deductible; and one-half of the amount of qualified gifts in excess of $\$ 200,000$ is deductible. I.R.C. \& 2523(a)(2).

38. See generally H.R. REP. No. 1380, 94th Cong., 2d Sess. 1 (1976), reprinted in [1976] U.S. CODE CONG. \& AD. NEWS 3356.

39. I.R.C. \$\$ 2001(c), 2502(a).

40. The offsetting of gift taxes previously paid or payable against the current estate tax effectively insulates the adjusted taxable gifts from the imposition of a second transfer tax, even though (in form) an estate tax is payable thereon.

41. I.R.C. § $2001(\mathrm{~b})$. 
gift that is excluded under the annual exclusion allowance is not included in the donor's taxable gifts, the availability of the exclusion is extremely important in that the amount so excluded will not be added to the decedent's estate tax base and so will not increase the estate tax rates applicable to the decedent's taxable estate. ${ }^{42}$ Of course, if the donated property is included in the decedent's gross estate (because, for example, of a retained interest or power of the decedent), ${ }^{43}$ the qualification of the gift for the annual exclusion is far less important.

Prior to 1977 , the proceeds of a life insurance policy assigned to another by the insured within three years of his death might have been included in the insured's gross estate as having been made in contemplation of death. The Tax Reform Act of 1976, as was noted above, replaced the subjective contemplation of death rule with a rule of automatic inclusion of all gifts made within three years of death. ${ }^{44}$ The new law also provides, however, that "any gift excludable in computing taxable gifts by reason of section 2503(b)" (that is, by virtue of the annual exclusion) is also exempt from section 2035's inclusion in the donor's gross estate. ${ }^{45}$ An important question is whether property which was worth less than $\$ 3,000$ when the decedent made the gift, but which substantially appreciated in value in the interval between such transfer and the decedent's death, is fully excludable from the decedent's gross estate under section 2035(b)(2), or whether it is excludable only to the extent of the dollar amount that was excluded from the gift tax when the gift was made. Under the former view, if an insured assigns to a third party all incidents of ownership in a $\$ 100,000$ (face value) life insurance policy prior to the accumulation of a terminal reserve in excess of $\$ 3,000$, and he dies within three years of making the gratuitous assignment, not only will he pay no gift tax, but the policy's proceeds will be excluded from his gross estate. ${ }^{46}$ The literal language of section 2035 (b)(2) suggests that the entire $\$ 100,000$ proceeds are excludable from the insured's gross estate, since the exclusion of a "gift" normally refers to the property which was donated and not merely to the value of such property at the time of the gift. Several tax commentaries have reported a rumor that

42. A gift to the decedent's spouse will not constitute an adjusted taxable gift to the extent that it qualifies for a marital deduction. However, such gifts which qualify for the marital deduction may have an adverse estate tax consequence in that they will cause a reduction in the maximum limitation on the estate tax marital deduction if the aggregate of such gifts at the time of the decedent's death is less than $\$ 200,000$. Id. $\$ 2056$ (c)(1)(B).

43. See id. \$§ 2036, 2038.

44. Tax Reform Act of 1976, Pub. L. No. 94-455, § 2001(a)(5), 90 Stat. 1520, 1848 (codified at I.R.C. § 2035). See notes 3-4 supra and accompanying text.

45. I.R.C. $\$ 2035(b)(2)$.

46. See Ditz, Life Insurance Can Solve Many Dilemmas of Estate and Gift Planning Under New Rules, 4 Est. Plan. 130, 130-31 (1977); Congress Prepares to Reopen Loopholes as Well as Close Them in Its Tax Measure, Wall St. J., Mar. 18, 1977, at 38, col. 1; 111-3d TAX MNGM'T (BNA) A-21 (Changes \& Additions 1977). 
the Service will adopt the alternate interpretation of section 2035(b)(2), and thus, in our example, would include a little less than $\$ 100,000$ in the insured's gross estate (that is $\$ 100,000$ less the value of the policy at the date the insured gave it away). ${ }^{47}$ Regardless of the ultimate construction of the current statutory language, it is likely that Congress will resolve the matter by statutory amendment. ${ }^{48}$ Indeed, on April 28, 1977, Congressman Ullman introduced a bill which would limit the exclusion from section 2035 to the entire amount of property given to a donee who did not receive a taxable gift from the donor within that year, but the bill would preclude a transfer "with respect to a life insurance policy" from being so excluded from section $2035 .{ }^{49}$ This bill was passed by the House on October 17, $1977,{ }^{50}$ and is currently pending before the Senate. If this bill is adopted, the qualification of an insured's assignment of a life insurance policy for an annual exclusion will continue to reduce the size of his estate tax base if the "gift" is not included in his gross estate (that is, the exclusion will reduce the amount of his adjusted taxable gifts); but the exclusion will have no estate tax consequence if the insured dies within three years of making the assignment so that section 2035 is applicable. However, if after assigning a policy insuring his life, the insured continues to pay the premiums for the policy (and thereby makes additional gifts), the availability of the gift tax annual exclusion for such payments may have estate tax significance as well. The House Report on the bill ${ }^{51}$ states that the bill's prohibition against excluding from section 2035 transfers "with respect to a life insurance policy' does not apply to the payment of premiums but only to a transfer of the policy itself. ${ }^{52}$

47. See 46 J. TAX. 255 (Apr. 1977); 111-3d TAX MNGM'T (BNA) A-21, supra note 46. See also JoInt COMm. on TAXation, General Explanation of the TAX REForm ACT of 1976, 94TH CONG., 2D SESS. 529 (1976).

48. See Congress Prepares to Reopen Loopholes as Well as Close Them in Its Tax Measure, supra note 46.

49. H.R. 6715, 95th Cong., 1st Sess. § 3(f) (1977). The Treasury Department's recommendations on H.R. 6715 deal with the "within three years of death" in a simple, direct and reasonable fashion. See Statement of Donald C. Lubick, Deputy Assist. Sec. of Treas., to House Ways and Means Committee (Sept. 8, 1977), reprinted in DAILY TAX REP. (BNA) No. 175, at J-10 (Sept. 8, 1977). The Treasury Department recommends that section 2035(a) and (b) be repealed and that section 2035 (c), which deals with the grossing up of gift taxes paid within three years of death, be retained and redesignated as section 2035(a). Sections 2036 and 2042 (life insurance) would be amended by adding a three-year rule to those provisions. If Congress adopts these changes, it should be alert to the fact that the operation of a number of other code provisions turns on the proportion of certain assets to the value of a decedent's gross estate. The integrity of those provisions should be protected. See, e.g., I.R.C. $\$ \S 303,2032$ A, 6166, 6166 A.

50. 123 CoNG. REC. H11,112 (daily ed. Oct. 17, 1977).

51. H.R. REP. No. 700, 95th Cong., 1st Sess. 74 (1977).

52. In the discussion above, no attention was given to the effect of a beneficiary's payment of premiums between the date on which the policy was assigned and the date of the insured's death. The major purpose of this Article is to examine the tax effect of such premium 
Since qualification for the annual exclusion will, in many cases, be extremely significant to the tax consequences of making a gift of an insurance policy, it may be critical to qualify a gift of a policy and subsequent premium payments thereon as gifts of a present interest. In general, a gift in trust of a life insurance policy (and premium payments made thereafter by the insured) will be treated as a gift of a future interest. ${ }^{53}$ Even where the beneficiary of the trust is given an immediate right to trust income, a gift to the trust of a life insurance policy is a gift of non-income-producing property, and thus ordinarily is treated as a gift of a future interest. ${ }^{54}$ If, however, the income beneficiary has the power to demand conversion of trust principal into income-producing assets, the gift of the income interest in the value of the policy may qualify as a present interest and, thus, be eligible for the annual exclusion. ${ }^{55}$ Also, if the beneficiary of the trust can demand payment of the trust estate at any time, the property transferred to the trust will qualify as the gift of a present interest. ${ }^{56}$

\section{ASSIGNMENT OF OWNERSHIP MORE THAN THREE YEARS PRIOR TO THE INSURED'S DEATH}

If, more than three years before his death, an insured assigns to another (whether the assignment is made outright or in trust) all incidents of ownership in a life insurance policy, the proceeds of the policy will not be included in the insured's gross estate, provided that he does not retain or subsequently acquire (directly or indirectly) any incident of ownership. Section 2035 does not apply since, on its terms, that provision covers only transfers made within three years of the transferor's death. The assignment, of course, is subject to the gift tax, and the value of the policy at the time of the assignment (less any annual exclusion that was allowed) is included in the insured's estate tax base as an "adjusted taxable gift,"57 except to the

payments, and that issue is discussed later in this piece. See text accompanying notes 97-122 infra.

53. See, e.g., Treas. Reg. \$25.2503-3(c), Ex. 2 (1958). But cf. Rev. Rul. 76-490, 1976-2 C.B. 300 (a gift in trust of a group term life insurance policy was held to have no ascertainable value, therefore, no taxable gift occurred; subsequent premium payments which were attributed to the insured were deemed eligible for the annual exclusion). See also Ryerson v. United States, 312 U.S. 405 (1941); Jesse S. Phillips, 12 T.C. 216 (1949).

54. See Rev. Rul. 69-344, 1969-1 C.B. 225.

55. See Rosen v. Commissioner, 397 F.2d 245 (4th Cir. 1968). Cf. Treas. Reg. $\S \S$ 20.2056(b)-5(f)(4), 25.2523(e)-1(f)(4) (1958) (in order for a trust to qualify for an estate or gift tax marital deduction, the principal must either be funded with income-producing assets or the beneficiary must have the power to convert the nonproductive assets).

56. Harbeck Halsted, 28 T.C. 1069, 1074 (1957), acq., 1958-1 C.B. 5; cf. Gilmore v. Commissioner, 213 F.2d 520 (6th Cir. 1954) (gift of corporate stock in trust, to be transferred to minor beneficiaries upon demand, qualified for annual exclusion even though trustees were authorized to invest in non-income producing investments).

57. I.R.C. § 2001(b). 
extent that the assignment qualified for the gift tax marital or charitable deduction.

If the assignment was not made to the insured's spouse, and the insured and his spouse elected to split the gift under section 2513 , then only the insured's one-half share (less his annual exclusion, if any) is included in the insured's adjusted taxable gifts. The other one-half share of the gift (less any annual exclusion allowed to the non-donor spouse) will be included in the estate tax base of the non-donor spouse on her death.

The question of whether an insured possessed an incident of ownership in a policy at his death can raise difficult issues which are beyond the scope of this Article. One current area of controversy concerns the question of whether an insured's possession of control over a policy in a purely fiduciary capacity constitutes an incident of ownership for purposes of section 2042. ${ }^{58}$ This Article, however, focuses on the consequences where the insured parted with all incidents of ownership prior to his demise.

\section{A. Payment of Premiums by the Insured.}

If, after assigning ownership of a policy to another, the insured continues to pay the premiums for the policy, those payinents inay cause transfer tax consequences. The amounts paid which are not excluded by the annual exclusion will be subject to the gift tax, but, in appropriate cases, the donor will qualify for a gift tax marital or charitable deduction for all or part of such payments. To the extent that the premium payments qualify for the gift tax marital deduction, however, they may lower the ceiling on the amount deductible under the estate tax marital deduction on the donor's death. ${ }^{59}$

Any premium payments made more than three years prior to the insured's death are included in his estate tax base as "adjusted taxable gifts" to the extent that such payments were not excluded by the annual exclusion or deductible as inarital or charitable deductions. ${ }^{60}$ Premium payments made by the insured within three years of his death do not

58. See note 2 supra. This issue often arises where one spouse owns a policy insuring the life of the other spouse and the policyholder dies first, bequeathing the policy in trust, and naming the insured spouse as one of the trustees. On the subsequent death of the insured spouse, the proceeds may be included in his gross estate if his fiduciary powers constitute an incident of ownership. The courts are divided on the issue of which fiduciary powers will cause inclusion of the proceeds. The Commissioner has ruled that when the proceeds are so included in the insured's spouse's gross estate, due to the incidents of ownership held as trustee, no credit will be allowed under section 2013 for the estate tax paid by the non-insured spouse's estate on the value of the policy at the non-insured spouse's death. Rev. Rul. 77-156, 1977-1 C.B. 269.

59. I.R.C. $\S 2056(\mathrm{c})(1)(\mathrm{B})$.

60. If split gift treatment under section $\mathbf{2 5 1 3}$ was elected for such payments, the portion of the payments attributable to the insured's spouse is excluded from the insured's estate tax base. 
constitute adjusted taxable gifts, since such payments either will be included in his gross estate under section 2035 or will be excluded under section 2035(b)(2). ${ }^{61}$ The question of the amount includable under section 2035 because of premium payments made by the insured within three years of his death, once a controversial issue, has been settled for some years now. The nature of this controversy and its ultimate resolution, though, are worthy of note.

\section{B. The Constructive Transfer Principle and its Proper Limits.}

In 1967, the Commissioner issued a Revenue Ruling which adopted the position that a premium payment constituted a transfer of an interest in the policy, and that the interest would be measured by the proportion that the amount of the premium bore to the total amount of premiums that had been paid by the time of the insured's death. ${ }^{62}$ Accordingly, on an insured's death, the Commissioner sought to include in the insured's gross estate that proportion of the insurance proceeds equal to the ratio that the amount of premiums paid by the insured within three years of his death bore to the aggregate amount of premiums paid on the policy by the time of his death. ${ }^{63}$

To support his argument, the Commissioner relied on certain language in the 1929 decision of the Supreme Court in Chase National Bank v. United States ${ }^{64}$ In Chase, the insured had purchased life insurance, retained incidents of ownership and named his wife as beneficiary. The insured, who died within two years of procuring the insurance, had paid all premiums due on the policies. The insured's estate challenged the constitutionality of the statute (the antecedent of section 2042(2)) which subjected the insurance proceeds to estate taxation. The estate contended that the tax was one on property itself (and therefore an unconstitutional unapportioned direct tax) rather than a tax on a "transfer" of property. This was so, the argument went, because the insured had never transferred the proceeds to the beneficiary; rather, the beneficiary had acquired the proceeds directly from the insurer ${ }^{65}$ In upholding the validity of the tax, the Supreme Court held that in substance the insurance proceeds had been transferred by the insured to the beneficiary, since his instruction to the insurer to pay the

61. If the premium payments made by the insured within three years of his death are treated as split gifts by the insured and his spouse, the portion allocated to the spouse (including the amount thereof that qualified for an annual exclusion) nevertheless will be captured in the insured's gross estate by section 2035 .

62. Rev. Rul. 67-463, 1967-2 C.B. 327.

63. Id. The position adopted by the Commissioner in 1967 applied only to premium payments made in contemplation of death. Because of the 1976 Act's substitution of an automatic inclusion rule for the contemplation of death test, this Article omits from the discussion of section 2035 any reference to the subjective motive of the donor.

64. 278 U.S. 327 (1929).

65. Id. at 334 . 
proceeds to his wife constituted a procurement of the proceeds by him for delivery to his wife. The Court determined that a person who purchases property from another to be delivered to a third party is to be treated as having transferred that property to the third party, and indicated that this principle would apply in interpreting the word "transfer" in the Code as well as in deciding the constitutionality of a particular provision. ${ }^{66}$

The courts, however, uniformly rejected the Commissioner's reliance on the Chase holding in the situation under discussion. ${ }^{67}$ In so doing, they did not repudiate the Supreme Court's construction of the meaning of "transfer," but rather deemed that construction not to be determinative of the problem at hand. The clearest statement of the rationale for rejecting the Commissioner's position ${ }^{68}$ was given by the Fifth Circuit in First National Bank of Midland v. United States: ${ }^{69}$

The actual essence of the Government's position is that it wishes to place a decedent who pays the premiums on a policy owned by another on the same footing with one who physically transfers the policy itself. It is said that the . . . [policyholders] received insurance benefits and not cash and that the payment of each and every premium helped to produce the proceeds. The answer to this, however, . . . [is] that the rights maintained belonged to the owners, not to the decedent, and were thus neither transferred nor transferrable by the decedent. ${ }^{70}$

Following these defeats in the courts, the Commissioner reconsidered his position and issued Revenue Ruling 71-497, which revoked his 1967 ruling and conceded that only the dollar amount of premiums paid by the insured within three years of his death is included in his gross estate. ${ }^{71}$ In Revenue Ruling 71-497, the premiums were paid on both a whole life insurance policy and on a term insurance policy.

66. Id. at 337-38.

67. See First Nat'l Bank of Midland v. United States, 423 F.2d 1286, 1288 (5th Cir. 1970); Gorman v. United States, 288 F. Supp. 225, 228-31 (E.D. Mich. 1968); Estate of Coleman, 52 T.C. 921, 923-24 (1969). See also Estate of Chapin, 29 T.C.M. (CCH) 11, 15-16 (1970); Lowndes \& Stephens, Identification of Property Subject to the Federal Estate Tax, 65 MrCH. L. REv. 105, 124-25 (1966); Note, Section 2035 as a Basis for Including Life Insurance Proceeds in the Gross Estate of Insured Who Paid Premiums on a Policy Owned By Another Person, 67 MICH. L. Rev. 812 (1969).

68. Even if the Commissioner had prevailed in arguing that there was a constructive transfer of a portion of the insurance proceeds, the portion includible should not have been figured on the basis of the Commissioner's formula. The Commissioner's formula undoubtedly was derived from the old payment of premiums test which Congress eliminated from section 2042 in 1954. The failings of the premium payment test are discussed later in this Article. See text accompanying notes $105-10$ infra.

69. 423 F.2d 1286 (5th Cir. 1970); accord, Bintliff v. United States, 462 F.2d 403 (5th Cir. 1972).

70. 423 F.2d at 1288.

71. Rev. Rul. 71-497, 1971-2 C.B. 329, revoking Rev. Rul. 67-463, 1967-2 C.B. 327. Of course, the amount of such premiums may be excluded from the insured's gross estate under 
Revenue Ruling 71-497 also considered the proper treatment of an insured's purchase of an insurance policy for another within three years of the insured's death. The situation described in the ruling was that nine months before his death the insured purchased a one-year term accidental death policy; his children were designated as the owners and beneficiaries of that policy. Thus, while the insured paid the premium for the policy, at no time did he possess an incident of ownership in the policy. The Commissioner ruled that under section 2035 the entire proceeds of the accidental death policy were includable in the insured's gross estate, not merely the dollar amount of the premium for the policy. The crux of the Commissioner's decision lay in his determination that the substance of the transaction was that the insured had transferred ownership of the policy to his children and had not merely paid a premium on a policy that they owned. ${ }^{72}$ The Commissioner again relied on the Chase National Bank case, and this time the Commissioner's position was sustained by the courts, coincidentally in a decision of the Fifth Circuit, Bel v. United States. ${ }^{73}$

In $\mathrm{Bel}$, the insured had each year purchased, with community funds, a one-year term accidental death policy in the name of his three children. The insured died within ten months of acquiring the last such policy. Referring to the Chase National Bank opinion and relying on section 2035 rather than section 2042, the Fifth Circuit treated the insured as having assigned the policy itself to his children within three years of his death and accordingly included half of the proceeds (the insured's community share) in his gross estate. While explicitly recognizing that the insured never possessed any incident of ownership, the court concluded

that section 2042 and the incidents-of-ownership test are totally irrelevant to a proper application of section 2035. We think our focus should be on the control beam of the word "transfer." The decedent, and the decedent alone, beamed the accidental death policy at his children, for by paying the premium he designated ownership of the policy and created in his children all of the contractual rights to the insurance benefits. These were acts of transfer. The policy was not procured and ownership designated and designed by some goblin or hovering spirit. Without . . . [the decedent's] conception, guidance, and payment, the proceeds of the policy in the context of this case would not have been the children's. His actions were not ethereally, spiritually, or occultly actuated. Rather, they constituted worldly acts which by any other name come out as a "transfer." Had the decedent, within three years of his death, procured the policy in his own name and immediately

section 2035(b)(2) if the premium payments qualified for the annual exclusion, but it should be borne in mind that it is likely that Congress will soon amend section 2035 . See note 48 supra.

72. 1971-2 C.B. 330.

73. 452 F.2d 683 (5th Cir. 1971), cert. denied, 406 U.S. 919 (1972). 
thereafter assigned all ownership rights to his children, there is no question but that the policy proceeds would have been included in his estate. In our opinion the decedent's mode of execution is functionally indistinguishable. Therefore, we hold that the action of the decedent constituted a "transfer" of the accidental death policy within the meaning of section 2035 , and that the district court erred in failing to include... [the decedent's] community share of the proceed value of the policy in his gross estate. ${ }^{74}$

The courts (led by the Fifth Circuit in each instance) have, therefore, rejected the use of the constructive transfer principle in the case of payments of insurance premiums on policies owned by another, but accepted its use in the case of original purchases of policies in the name of another. In each case, however, the donor purchased something of his choosing from the insurance company for the donee. From this standpoint, both cases are quite different from a situation clearly outside the proper limits of the constructive transfer principle, for example, where the donor gives cash to a donee to do with it as the donee sees fit. It should be equally clear, moreover, that the use of the constructive transfer principle is fully warranted in the case of an original purchase of a policy for a donee. ${ }^{75}$ Indeed, it would be difficult to think of a case which would fall more clearly within the proper limits of that principle. $^{76}$

74. 452 F.2d at $691-92$.

75. Although both Revenue Ruling 71-497 and Bel concerned accidental death policies, the principle of constructive transfer is of course applicable to the original purchase in the name of a donee of other types of policies. The difficulty that purchasers of accidental death policies have encountered may have been engendered by the fact that they purchased one-year term policies (which is the customary period for such insurance), so that each annual premium is really the acquisition of a new policy. If an insurer were to issue a five-year term accidental death policy with premiums payable in five annual installments, it is problematic whether the assignment of such a policy more than three years before the insured's death would avoid the reach of section 2035 if the insured paid the premium installments. It is quite possible that each installment would be treated as the purchase of a new policy. However, if the insured prepaid the premiums for the entire five-year term and assigned the policy more than three years before his death, the proceeds should not be included in his gross estate. An interesting question arises if the following plan were adopted: the insured acquires a twenty-year term accidental death policy with premiums payable in annual installments; he pre-pays three years' installments and immediately assigns the policy to another; each year, he pre-pays the premium for the fourth year hence. If he lives for more than three years after making the assignment, arguably the proceeds should not be included under section 2035 , since he both paid the premium for the policy for the year of his death and assigned away the policy more than three years before his death. The nature of the scheme is obvious, but an insured may have little to lose by trying it. On the other hand, it is so unlikely that accidental death insurance will mature that it probably is not worth embarking on a plan of this type, especially since the avoidance of estate taxes if the policy does mature is uncertain. The simplest and most promising method of seeking to avoid section 2035 is to have a beneficiary apply for and purchase the accidental death insurance policy with the beneficiary's own funds, funds that were not given to him by the insured for the purpose of purchasing the policy.

76. Other situations have recently been held to fall within the constructive transfer princi- 
Why then, does the situation where the insured pays premiums within three years of his death on a policy owned by another not also fall within the proper limits of the constructive transfer principle? Simply put, it is because the item of property that the donor acquires for the donee when he purchases an insurance policy for the donee, a situation where the constructive transfer principle is applied, is one that he could have acquired for himself and then given to the donee. But when an insured pays the premiums on a policy already owned by the donee, the donor's premium payment purchases for the donee items of property that the donor could not have acquired for himself - an increase in the equity reserve in the policy owned by the donee plus insurance coverage ${ }^{77}$ for a certain period. Only the donee, the policyholder, could acquire these property interests because it is the donee, not the insured, who then owns the right of continuation component of the policy. In the words of the Fifth Circuit in First National Bank, they were not "transferable by the decedent."

In sum, the constructive transfer principle enunciated by the Supreme Court in Chase is properly limited, at least insofar as section 2035 is concerned, to purchases in the name of the donee of property interests which the donor could have acquired for himself. To demonstrate that this is so, some exploration of the purpose and function of section 2035 is in order.

\section{The Purpose and Function of Section 2035.}

The purpose of section 2035 is to prevent estate tax avoidance by the use of hfetime gifts as a substitute for testamentary gifts. ${ }^{78}$ The first step in applying section 2035 is therefore the determination of what property

ple, and properly so. For example, where a decedent had his wife apply for term insurance on the decedent's life and where the decedent paid the premiums thereon, the decedent was deemed to have transferred the policy to his wife. First Nat'l Bank of Oregon v. United States, 488 F.2d 575 (9th Cir. 1973). Similarly, where a decedent created an irrevocable trust, directed the trustee to acquire $\$ 100,000$ of insurance on the decedent's life out of cash transferred to the trust, and died within six months thereafter, the Sixth Circuit held that for purposes of section 2035 the decedent was deemed to have transferred the $\$ 100,000$ policy to the trustee. Detroit Bank \& Trust Co. v. United States, 467 F.2d 964 (6th Cir. 1972), cert. denied, 410 U.S. 929 (1973).

Rev. Rul. $76-490$, 1976-2 C.B. 300 provides an interesting example of a constructive transfer by the insured of premium payments. In that ruling, the insured had assigned to an irrevocable trust all of his interest in a group term life insurance policy granted by the insured's employer. The employer voluntarily continued to pay the premiums for the assigned policy. The Commissioner ruled that each premium payment made by the employer was an indirect gift from the insured to the assignee of the policy and was therefore subject to gift tax. Surprisingly, however, the Commissioner ruled that each such gift was not a transfer of a future interest and therefore qualified for the $\$ 3,000$ annual exclusion.

77. As used herein, "insurance coverage" refers to the amount of difference between the proceeds payable on the death of the insured and the policyholder's equity reserve in the policy.

78. See, e.g., Estate of Compton v. Commissioner, 532 F.2d 1086, 1087 (6th Cir. 1976); Bel v. United States, 452 F.2d 683, 687 (5th Cir. 1971), cert. denied, 406 U.S. 919 (1972). 
interest was transferred by the decedent, thereafter including in the decedent's gross estate the value of that interest determined as of the estate tax valuation date ${ }^{79}$ (typically, the date of the decedent's death). The theory is that the property's value at date of death would have been included in the decedent's gross estate had he not made the inter vivos transfer. The function of section 2035 is therefore to prevent the decedent from reducing his estate tax base by transfers made shortly before his death. The 1976 Act's integration of estate and gift taxes reduces the significance of section $2035,{ }^{80}$ but it remains important where the value of the donated property appreciates substantially after the gift was made, as typically is the case with life insurance where the insured dies shortly after the assignment. ${ }^{81}$

Since the function of section 2035 is to prevent the decedent from reducing his estate tax base by transfers made shortly before his death, that section should include only property interests which potentially could have been included in the decedent's estate tax base had he not made a transfer. It is for this reason that the constructive transfer principle is properly limited to property interests which the decedent could have acquired for himself. If the decedent could not have acquired the property interest for himself, his purchase of such an interest for another removes from his estate only the dollar amount actually expended by him. There are, of course, few property interests which a person can acquire for someone else but cannot acquire for himself. The interest conferred on a policyholder when a donor pays premiums on the policy is not the only one, however. Another arises where a third party owns property on which a payment is due. A donor's gratuitous payment of the debt constitutes a gift of the payment itself and does not constitute a gift of a fraction of the property for which the debt was incurred. Since the donor did not own the property, no fraction of the property could have been included in his gross estate if he had not made a gift of the payment; section 2035 should therefore reach only the payment itself, as that is the only property which was removed from the decedent's estate by the gift. So, if $X$ owned real estate subject to a mortgage, $Y$ 's satisfaction of a mortgage installment payment is a gift of the dollar amount expended. The same rationale applies to the payment of life insurance premiums on a policy

79. I.R.C. $\$ \S 2031(\mathrm{a}), 2032(\mathrm{a})$.

80. The 1976 Act amended section 2035 to require the inclusion in the decedent's gross estate of all gift taxes paid on gifts made by the decedent within three years of his death. This provision applies only to gifts made after 1976.

81. Scction 2035 is also of great importance in that it can operate in conjunction with other Code sections to cause the inclusion in a decedent's gross estate of property whose value far exceeds that of the interest or power transferred or released by the decedent within three years of his death. For example, a grantor's transfer, shortly before his death, of a life income interest in a trust that he had previously created, and in which he had retained such an interest, will cause the value of the trust assets to be included in his gross estate under the combined application of sections 2036 and 2035. 
owned by another. Since the insured did not own, and could not acquire, an interest in the policy on which he paid premiums, no interest in the policy could have been included in his gross estate had he not paid the premiums.

\section{AsSigNMENT OF OWNERShIP WITHIN THREE YeARS OF DEATH}

If a donor were to make an outright gift of an item of property within three years of his death, the value of the donated property will generally be included in his gross estate, since that value would have been so included if he had not made the transfer. This rule is equally applicable where periodic payments must be made subsequently in order to retain the property. For example, the donee of a parcel of real estate may be required to pay real estate taxes and to make mortgage payments in order to prevent a tax sale or a foreclosure. Notwithstanding that encumbrance, the value of the property (less the value of the donee's improvements and contributions) will be included in the donor's gross estate if he dies within three years. Even if the donee failed to make the required payments and lost the realty in a tax or foreclosure sale, the value of the donated realty itself (presumably reduced by the amount of debt on the realty at the time of the gift) will be included in the donor's gross estate. ${ }^{82}$ Of course, if the donor had retained the property,

82. See Humphrey's Estate v. Commissioner, 162 F.2d 1 (5th Cir.), cert. denied, 332 U.S. 817 (1947); Rev. Rul. 72-282, 1972-1 C.B. 306. See also Rev. Rul. 76-235, 1976-1 C.B. 277, where property transferred within three years of death was valued under section 2035 at the date of the donor's death, without reduction for a mortgage on the property taken out by the donee to secure a loan that did not benefit the donor.

The Commissioner's determination to value the donated property itself (at least where the gift was not made in trust) can create some peculiar consequences. For example, assume that a donor purchases a ticket for the Irish Sweepstakes for $\$ 2$, promptly giving the ticket to a donee. Subsequently, a horse is designated for that ticket and its value is thereby increased to $\$ 5,000$. If the horse wins the race, the amount payable on the ticket is $\$ 100,000$. The donee must decide whether to sell the ticket for $\$ 5,000$ or to hold the ticket and gamble on the horse's winning. If the horse loses, the ticket will be worthless. The donee elects to sell for $\$ 5,000$, and the race is run before the donor's death. Should the amount included in the donor's gross estate be either $\$ 100,000$ or zero, depending upon whether the horse won? The position adopted by the Commissioner (and the courts) would seem to compel that result, but the question of whether the donor would have held onto the ticket is far more speculative than is the case with most donated properties (for example, stocks, bonds and realty).

It has been suggested (but the issue is unsettled) that the rule which states that the donated property itself is valued under section 2035 will not be applied by the Service to gifts made in trust; rather, the res of the trust will be valued as it exists at the donor's death. But see In re Kroger's Estate, 145 F.2d 901, 907-08 (6th Cir. 1944), cert. denied, 324 U.S. 866 (1945). The above suggestion has been criticized by several prominent commentators. See, e.g., C. LownDES, R. KRAMER \& J. MCCORD, supra note 27, at § 5.15; R. STEPHENS, G. MAXFIELD \& S. LiND, FEDERAL EsTATE AND GIFT TAXATION \$ 4-72 (3d ed. 1974); Lowndes \& Stephens, supra note 67, at 139. These criticisms are grounded on an assumption that the principal reason for focusing on the proceeds from the sale or exchange of donated property only if it was donated in trust is that the Service believes that it is feasible to trace the proceeds where they are held in trust, but it generally is not feasible to do so if they are not. The commentators have challenged that premise. However, it is possible to justify this distinction on a quite different conceptual 
he might not have made the required payments; the statute, however, operates on the implicit irrebuttable assumption that he would have done so. This assumption is a practical necessity in order for section 2035 to have meaningful significance. Any taxes paid by the donee should constitute a contribution by him that reduces the amount included in the donor's gross estate, ${ }^{83}$ but it is far from clear that such payments will be so treated. If the donor had retained the property, his payment of such taxes would have reduced his gross estate. Of course, he would have enjoyed an income tax deduction therefor, so that the net reduction in his estate might have been less than the tax payment; it would be administratively inconvenient, however, to attempt to compute the income tax savings the donor would have enjoyed from such a deduction. ${ }^{84}$ Any mortgage payments made by the donee will constitute a contribution by him; such payments will increase the owner's equity in the property and so must be treated as the donee's contribution in order to prevent an over-valuation of the interest transferred by the donor. Where, within three years of his death, an insured assigns to another all incidents of ownership in a policy insuring his life, the amount includible in the insured's gross estate, if any, depends upon whether subsequent premiums become due, are paid and if so, by whom.

\section{A. No Post-Assignment Premiums Become Due.}

If no post-assignment premiums become due because the insured dies within the period covered by the last premium payinent he made before assigning the policy, it is settled that the entire amount of the proceeds (assuming the inapplicability of section 2035(b)(2)) is included in the insured's gross estate. ${ }^{85}$ This is the correct result. By assigning the policy, the

ground. The refusal to trace the proceeds received by the donee of an outright gift constitutes a rejection of the claim that the donee should be treated as an agent of the donor, although a reasonable case can be made for treating the donee as the donor's representative for purposes of charging the donor with the donee's sale and reinvestment of donated property. While the donor retains no control over the donee's use of the donated property, they have an identity of interests in the property that comes close to justifying the treatment of the donor and the donee as a single tax unit insofar as the donated property is concerned. As already noted, however, the courts have uniformly declined to so treat the donee. On the other hand, where a donor makes a gift in trust, it typically will be a trust that he created and whose terms he dictated. Consequently, even though the settlor retains no continuing control over the trustee, the trustee could be treated as an agent of the donor for the limited purpose at hand, so that the trustee's shifting of investments would be attributed to the donor in determining the amount to be added to his gross estate.

83. See Treas. Reg. $\$ 20.2035-1(e)(1958)$. In the view of the authors, the amount included in the donor's gross estate should be reduced by the aggregate amount of tax paid by the donee.

84. Similarly, I.R.C. $\$ 691(\mathrm{~b})$ allows both an income and an estate tax deduction for an expense which constitutes a deduction in respect of a decedent, even though, if such item of expense had been satisfied prior to the decedent's death, the resulting reduction in the decedent's estate would have been mitigated by the tax savings obtained by virtue of the income tax deduction that would have been allowed.

85. See Berman v. United States, 487 F.2d 70 (5th Cir. 1973); Bel v. United States, 452 
insured of course transferred the underlying economic components therein. ${ }^{86}$ Since at the time of the insured's death, the value of the equity reserve component and the term insurance coverage component combine to equal the full amount of the proceeds paid, that is the amount that should be, and is, included in the insured's gross estate.

\section{B. Post-Assignment Premiums Become Due But Are Not Paid, Resulting in a Lapse of the Policy.}

If an insured lives long enough so that post-assignment premiums become due, but neither the donee nor the insured makes the required subsequent premium payments and thereby permits the policy to lapse before the insured dies, what amount, if any, should be included in the insured's gross estate? While it is conceptually a difficult question, perhaps the most significant comment to be made on this issue is that it does not appear ever to have arisen, suggesting either that the likely expectation of a donor that the premiums will be paid at least for the next few years is justified or that the issue has not been raised by the Service. Even though of little practical significance, the question is sufficiently interesting to warrant brief consideration.

While the result may appear harsh, it is possible (at least where the assignment of the policy was not made in trust) that the amount to be included should be the amount of proceeds that would have been payable on the policy if it had been kept in force, less the amount of premiums that would have been required to retain the insurance until the insured's death. ${ }^{87}$

The amount normally to be included under section 2035 is the value of the property transferred, without regard for whether the donee subsequently sold, exchanged or lost his interest in the property. ${ }^{88}$ As previously noted, the position of the Commissioner (and the several courts that have considered the issue) is that the actual property transferred by the decedent is included in his gross estate at its value at the estate tax valuation date, irrespective of whether the donee retained the property. ${ }^{89}$ The donee, however, can affect the value of the donated property by various ineans, such as by failing to maintain the property and protect it from deterioration.

Since the existence of an obligation to make payments in order to retain

F.2d 683 (5th Cir. 1971), cert. denied, 406 U.S. 919 (1972); Rev. Rul 71-497 (situation 2), 1971-2 C.B. 329.

86. See notes 6-9 supra and accompanying text.

87. The obligation to pay a premium to retain the insurance is roughly equivalent to an encumbrance on the property. The unpaid premium therefore should be deducted as a proper reflection of an outstanding debt-that is, the policy is treated as if it were still in existence, and in that event the unpaid premium would be a debt on the property.

88. See note 82 supra.

89. This rule may not of course apply to gifts in trust. See note 82 supra. 
property does not bar its inclusion under section 2035 (because of the implicit and irrebutable assumption that the donor would have made those payments), the donee's failure to make the payments should not affect the inclusion of the property. It could be argued, however, that the justification for assuming that the donor would have made the required payments exists only if such payments are actually made by the donor, the donee or by some other party, since the fact of payment evidences that there was an adequate economic motivation to make it. In the absence of actual payment, it might be argued that the possibility that the donor would have paid the premiums is too speculative. Contrary to those contentions, however, section 2035 focuses on the donor alone; and in general, except possibly for gifts in trust, the donor will not be charged (indirectly or otherwise) with the actions of the donee. The donor's motives and concerns will often differ substantially from those of the donee, so that the donee's failure to maintain the insurance protection is not a helpful guide to the probable course the donor would have taken if he had not assigned the policy. The donor's failure to pay the premium for the donee also provides little guidance, since his unwillingness to make additional gifts does not suggest the course he would have taken had he continued to own the policy.

If a policy lapses before the insured's death, can it be said to have any value, other than the value of the equity reserve component if it is a straight life policy? Where a donee of an outright gift dissipates his interest in donated cash or stocks or realty, the property exists at the date of the donor's death even though it is not owned by the donee at that time. Cash need not be traced since its value is deemed always to remain the same (of course, that is not true economically, but for tax purposes, dollars constitute the measure of value). If the donee sells or otherwise disposes of donated stock or realty or a painting, the donated property nevertheless is valued at the donor's death; again, however, the property does exist at that time. ${ }^{90}$ When a policy lapses, its term insurance coverage component ceases to exist and as a result has no value thereafter. If a donee were given stock which comprised a controlling interest in a corporation, and the donee mismanaged the company into bankruptcy before the donor's death two years later, the estate tax value of the stock would be zero, even though its reduction in value was caused by the donee. A donee can therefore affect the amount in the donor's gross estate by taking (or by failing to take) action which reduces the value of the property; in this respect, the donee is no different

90. An interesting question (similar to the lapsed insurance problem) could arise if the donated property were destroyed prior to the decedent's death. For example, if a painting the donee received were consumed by fire it would have a zero value. If cash the donee received were destroyed in a fire, that should reduce its value to zero for estate tax purposes, but tracing the burned cash to the original gift might be difficult. 
from any other person whose actions may alter the value of the donated property (for example, a re-zoning of donated realty may increase its value). The donee's actions (or inaction) affecting the value of the donated property are to be distinguished from the donee's retention of the donated property. Arguably then, a lapsed policy might be included in the insured's gross estate at a zero value, or at the value of its equity reserve component ${ }^{91}$ at the time of lapse if it is a straight life insurance policy.

Under another analysis, however, the value of a lapsed policy is much greater than zero. The lapse of an insurance policy bears some similarity, in substance, to the foreclosure of a mortgage on realty even though the risk coverage provided by the insurer ceases to exist on the lapse of the policy. The effect of the lapse is to shift the risk of the financial loss arising on the premature death of the insured from the insurer (who has assumed the risk under the insurance contract) to the assignee, who had been covered by the policy. In either case (the ownership of realty or of an insurance policy), the value of the bundle of rights involved can easily be determined at the donor's death, and the donee's actual benefit from the property is limited to its net value at the date the donee lost or surrendered the property. The value of the realty (on the donor's death or the alternate date), however, is included in the donor's gross estate even where the donee realized far less on the sale or foreclosure of the property; it might also appear reasonable to provide the same treatment for insurance coverage where the donee surrendered his insurance protection rights. It is therefore arguable that the lapse of a policy should not have a substantial impact upon the amount included in the insured's gross estate, unless the policy had been assigned by the donor in trust. If there is an anomaly in providing different treatment for policies transferred in trust, it exists because the Service's different treatment (which is by no means settled) of 'transfers in trust under section 2035 is anomalous. ${ }^{92}$ But, the only asset that the insured had to transfer was the claim against the insurer as contrasted to risk coverage in the abstract. As already noted, the insurer's obligation was terminated by the lapse. The resolution of this question depends upon whether the assignee's allowing the policy to lapse extinguishes the property interest transferred to him by the insured or merely changes it in form. Since self-insurance for a loss is not an asset, the assignee's assumption of risk (by releasing the insurer) cannot properly be viewed as a change in form of an asset but rather is the undertaking of a risk (i.e., a liability). The lapse of an insurance policy, therefore, should be treated as a termination of the transferred property. The question then remains as to how the terminated policy should be valued for purposes of determining the amount (if any) includable in the insured's gross estate.

91. See the text accompanying note 93 infra for a discussion of how the equity reserve component should be valued in this setting.

92. See note 82 supra. 
Section 2035 requires that the property transferred by the donor be valued as of the estate tax valuation date, which for convenience we treat as the date of his death. At the time that the policy lapsed, its value (if any) to the policyholder was the equity reserve component since neither of the other two components ${ }^{93}$ remained. In fact, the actual value of the policy to the policyholder was limited to its cash surrender value since that is all that he could realize on the property, and the additional value represented by the equity reserve is of benefit to a policyholder only where the policy is retained in force. If the insured had kept the policy and had allowed it to lapse, all that would have been included in his gross estate would be the unconsumed remainder of the policy's cash surrender value, and so no greater amount should be included where the policy lapsed in the hands of his assignee.

\section{Post-Assignment Premiums Become Due and Are Paid by the Insured.}

If the insured lives long enough so that post-assignment premiums become dur, and the insured pays those premiums, it is settled that the entire amount of the proceeds (possibly less some amount under section 2035(b)(2)) is to be included in the insured's gross estate. ${ }^{94}$ This result clearly is correct, but its demonstration requires some elaboration. The analysis used by the courts and the Commissioner has been incomplete, possibly because the result seems so intuitively correct that a complete analysis never seemed necessary. The failure of courts to spell out an analysis of this situation perhaps contributed to the difficulty the courts had in determining the amount includable when the assignee, not the insured, pays the post-assignment premiums.

Aside from the intuitive correctness of including the full amount of the proceeds when the insured pays the post-assignment premiums, how is this result justified conceptually? If we look at the transaction as we did when no post-assignment premiums became due, there might appear to be a problem. The portion of the proceeds attributable to the equity reserve component that the insured transferred to the donee should be included because that was transferred when the policy was assigned. But the value of the term insurance coverage component, that is, the insurance protection for the period

93. The other two components are the term insurance coverage and the right of continuation components.

94. Treas. Reg. \$ 20.2042-1(a) (1958). See, e.g., Estate of Compton v. Commissioner, 532 F.2d 1086 (6th Cir. 1976); Berman v. United States, 487 F.2d 70 (5th Cir. 1973); Vanderlip v. Commissioner, 155 F.2d 152 (2d Cir.), cert. denied, 329 U.S. 728 (1946). See also Estate of Silverman v. Commissioner, 521 F.2d 574, 576 (2d Cir. 1975). In Compton, the premiums on a group-term life insurance policy, which became due after the insured had assigned the policy, were presumably paid by the insured's employer. Nevertheless, the insured was deemed to be the transferor of the premiums. See Estate of Porter v. Commissioner, 442 F.2d 915, 919-20 (1st Cir. 1971); Rev. Rul. 76-490, 1976-2 C.B. 300. 
covered by the last pre-assignment premium, would be zero at the time of the insured's death, because by definition the insured outlived this period. How, then, is that portion of the proceeds made up of the insurance element (and that portion of the increase in the equity reserve beyond its value at the time of the assignment attributable to post-assignment premiums) to be included in the insured's gross estate? The explanation, as developed previously, is that there is a third economic component of a life insurance policy - the right of continuation component (the right to purchase insurance coverage for subsequent periods at a fixed price). ${ }^{95}$ When no post-assignment premiums become due, the term insurance coverage and equity reserve components combine to equal the full amount of the proceeds, and the right of continuation component is valueless. When post-assignment premiums do become due and are paid by the imsured, the term insurance coverage component is valueless but the right of continuation and the equity reserve components combine to equal the full amount of the proceeds.

Under a literal application of section 2035 the amount of premiums paid by the insured within three years of his death, less the $\$ 3,000$ annual exclusions if available, also would be included in the gross estate. There is no statutory bar to such a double inclusion and thus taxpayers must rely on an administrative or judicial judgment not to elevate the letter of the statute above its spirit. ${ }^{96}$ Assuming that the premium payments exceed the annual exclusion allowance, are not deductible and are not included in the insured's gross estate under section 2035, they should not be treated as adjusted taxable gifts for the same reason that they should be excluded from the reach of section 2035-the premium payments have been subsumed in the payment of the insurance proceeds on maturity, and since the proceeds are included in the insured's gross estate, the premiums should be excluded from both the insured's gross estate and his adjusted taxable gifts to prevent a doubling of the tax consequence.

\section{Post-Assignment Premiums Paid by the Assignee.}

1. Judicial Consideration of the Question. There are two cases dealing with the tax consequences of the assignee's having made the post-

95. See Guggenheim v. Rasquin, 312 U.S. 254, 257 (1941).

96. In a recent case arising under pre-1976 facts, the Commissioner sought to include in the insured's gross estate both insurance proceeds and the premiums paid thereon within three years of death and in contemplation thereof. A trial judge for the Court of Claims held that only the proceeds were includible because "it would be incongruous to include in the estate both the proceeds of the policy and the premiums paid to an insurance company to keep the policy in force." Peters v. United States, 77-2 U.S.T.C. (CCH) I 13,209, at 18,159 (Ct. Cl. Tr. Div. 1977).

An analogous situation arises where the proceeds of an insurance policy owned by a third party on a deceased shareholder's life are required by contract to be paid to the insured's estate as partial payment for his corporate stock. In such a case, the proceeds may be included in the insured's gross estate under section 2042(2) because of a retained incident of ownership. To 
assignment payments. The earher of these cases is Liebmann $v$. Hassett, ${ }^{97}$ a 1945 decision of the First Circuit under the Revenue Act of 1926. In Liebmann, the insured died two years after assigning incidents of ownership in a life insurance policy to his wife. The two annual premiums which were due between the assignment and the insured's death were paid by the wife. The executrix conceded on appeal that the policy was assigned in contemplation of death, but she questioned the method of valuing the policy. The court excluded from the insured's gross estate a portion of the proceeds of the policy equal to the ratio that the two premiums paid by the wife bore to the aggregate amount of premiums paid for the policy. The balance of the proceeds was included by the court in the insured's gross estate. In so doing, the court relied on the fact that, had the version of section 2042(2) then in effect been applicable, only a portion of the proceeds would have been included in the insured's gross estate due to the premium payment rule, which was then in vogue. The court held that it would be inconsistent to treat the insured as having transferred more under the antecedent of section 2035 than would have been included in the insured's gross estate under the antecedent of section 2042(2) had it been applicable. Because Congress abandoned the premium payment test in 1954, the Liebmann case has hittle precedential value in this area.

The decisions of the Tax Court and the Second Circuit in Estate of Morris $R$. Silverman ${ }^{98}$ are more recent and are therefore of far greater significance than is the First Circuit's decision in Liebmann. At age 60, Morris Silverman purchased a $\$ 10,000$ policy insuring his life, the premiums on which were payable monthly. Almost five years later, Morris assigned the policy to his son. Within six months, Morris died, and the assignment was held to have been in contemplation of death. ${ }^{99}$ The son paid the seven monthly premiums that became due after the assignment. At the Tax Court proceeding in Silverman, the Commissioner sought to include the entire $\$ 10,000$ proceeds of the policy in the insured's gross estate with no allowance for the seven monthly payments made by the assignee. ${ }^{100}$ The executor, however, contended that even if the policy had been assigned in contemplation of death, only the dollar amount of premiums paid by the

avoid double taxation in such cases, the courts typically will reduce the value of the decedent's stock by the amount of the insurance proceeds that are required to be paid to the insured's estate towards the purchase of those shares. See Kahn, Mandatory Buy-Out Agreements for Stock of Closely Held Corporations, 68 MiCH. L. REV. 1, 32-33 (1969).

97. 148 F.2d 247 (1st Cir. 1945).

98. 61 T.C. 338 (1973), aff'd, 521 F.2d 574 (2d Cir. 1975).

99. As previously noted, the 1976 Tax Reform Act substituted an automatic inclusion rule for the subjective "contemplation of death" test that was applicable when the facts of Silverman took place.

100. 521 F.2d at 575 . 
insured were includable in his gross estate. ${ }^{101}$ The Tax Court rejected the contention of both parties and included a portion of the proceeds:

The transfer of a life insurance policy in contemplation of death normally requires inclusion in the gross estate at face value . . . . In the instant case however, the petitioner paid all the insurance premiums after the assignment. Of total premiums amounting to $\$ 3,261.20$, petitioner paid $\$ 368.20$ or 11.29 percent and the decedent paid $\$ 2,893$ or 88.71 percent. Under these circumstances we feel that the petitioner contributed to the value of the policy, and it would be inappropriate to include in the gross estate that portion of the value which petitioner contributed.

Throughout its existence, including the time of transfer, the policy had a face value of $\$ 10,000$. At the time of the decedent's death however, a certain number of premiums were required to keep the face value intact. It is apparent, therefore, that at the time the decedent transferred the policy, only a portion of the premiums necessary to maintain the face value payment on death had in fact been paid. The petitioner's continued premium payments were thus a vital part of the consideration necessary to secure full payment on the insurance policy on decedent's death. To hold otherwise would tax the estate on an asset greater than that which the decedent transferred . . . . We therefore hold that the decedent's estate must include that portion of the face value of the life insurance policy which the decedent's premium payments bore to all premium payments. ${ }^{102}$

On appeal, the Second Circuit affirmed the Tax Court, rejecting the executor's alternative contentions that only the cash surrender value of the policy or the premiums paid by the insured should be included in his gross estate. ${ }^{103}$ In that appeal, the Commissioner chose to defend the Tax Court's decision rather than renew his contention for the inclusion of the entire amount of the proceeds. The Second Circuit was critical of the Tax Court's decision to pro-rate the proceeds, and strongly suggested that the proper treatment would be to include in the insured's gross estate the $\$ 10,000$ proceeds less the $\$ 368.20$ of premiums paid by the assignee. ${ }^{104}$ While the Government's brief also suggested that this was the proper treatment, it did not urge the point on appeal but was content to defend the Tax Court's prorata allocation.

2. Return of the Percentage of Premiums Test. The position adopted by the Tax Court in Silverman is reminiscent of the percentage of premium test that was once employed by the estate tax laws as part of the antecedents

101. Id.

102. 61 T.C. at $342-43$ (citations omitted).

103. 521 F.2d at 577.

104. Id. at 578 . 
to section 2042(2). This test was eliminated by Congress, however, when it adopted the 1954 Code. As noted previously, the congressional rejection of the premium payment test was criticized by a minority of Congressmen and by a few tax commentators. ${ }^{105}$ While the Tax Court's decision by no means signalled a return to that test in all situations, it may well have been based on the identical assumptions that led some to favor the now discarded formula, and a brief digression is warranted to examine the merits and failings of the premium payment test. The dissenting members of the committee that recommended the abolition of the premium payment test stated in part:

It is sought to justify the change as merely putting life insurance on a par with other property which may be given away free from estate tax if the gift is not made "in contemplation of death." But life insurance is not like other property. It is inherently testamentary in nature. It is designed, in effect, to serve as a will, regardless of its investment features. Where the insured has paid the premiums on life insurance for the purpose of adding to what he leaves behind at his death for his beneficiaries, the insurance proceeds should certainly be included in his taxable estate. ${ }^{106}$

The authors of C. Lowndes, R. Kramer \& J. McCord, Federal Estate and Gift Taxes, a prominent treatise on the subject of estate and gift taxation, also were critical of the elimination of the payment of premium test. The authors state:

Life insurance should not be taxed like other property because it is not like other property. Regardless of whether or not life insurance is 'inherently testamentary', which, after all depends on how one defines 'inherently testamentary', the abolition of the premium payment test opens the door for substantial estate tax avoidance. A man can pass along unlimited amounts of property at his death without encountering the estate tax by investing in life insurance and divesting himself of all incidents of ownership in the insurance during his life.

It is true that a man can avoid an estate tax if he makes a complete gift of other kinds of property during his life. He will, however, incur a gift tax on the property given away. Moreover, he will suffer the inconvenience which the loss of the property entails. Life insurance may be given away before it has built up any substantial reserve values with little or no gift tax. The principal present enjoyment which an insured derives from life insurance is the thought that it will take care of his dependents after his death. In the ordinary case this will not be diminished by an assignment of the insurance to the intended beneficiary. It is true that a man who irrevocably assigns his insurance during his life cannot cash in the insurance to meet financial emergencies

105. See notes $26-27$ supra and accompanying text.

106. H.R. REP. No. 1337. supra note 26, at B14, reprinted in [1954] U.S. CodE CoNG. \& AD. NEWS $4025,4608$. 
which may later arise. This detriment may, however, be more theoretical than actual, since the assignee will normally be one of the insured's intimate family group who will readily re-assign the insurance should the need arise..$^{107}$

Despite the stature of the supporters of the premium payment test and the vigor of their support, the test has nothing to commend it and was properly abandoned by Congress. There is no rational connection between the amount of insurance proceeds that would be taxed under a premium payment test and the fundamental principles of estate taxation that underlie the treatment of all other property items. For example, assume that Helen owned a fully paid up policy insuring her life in the amount of $\$ 50,000$. On her 68th birthday, Helen assigned the ownership of the policy to her niece, Matilda. The cash surrender value of the policy at that date was $\$ 42,000$. Since the policy was fully paid up, no further premiums were due. Helen died four years later, and the proceeds of the insurance were paid to Matilda. All but a few thousand dollars of the proceeds are attributable to the equity reserve component in the policy that Helen assigned to Matilda more than three years prior to her death. Under current law, none of the proceeds will be included in Helen's gross estate; but the value of the gift (less the gift tax annual exclusion) will be included in Helen's estate tax base under the unified rate system. If a premium payment test were re-adopted, and if the policy qualified as insurance, ${ }^{108}$ all of the proceeds would be included in Helen's gross estate. From a policy viewpoint, however, there clearly is no justification for including any of the insurance proceeds in Helen's gross estate. There can be no reason to distinguish Helen's assignment of the life insurance policy from a gift of other property such as real estate.

Lowndes, Kramer and McCord apparently believe that the abuse in the current estate tax treatment of life insurance proceeds occurs most flagrantly where the life insurance is "given away before it has built up any substantial reserve values with little or no gift tax." 109 The following two examples demonstrate that there is no basis for that concern.

Assume that in Year One, $X$ acquired a whole life policy insuring his life in the amount of $\$ 100,000$. The premium for the policy was $\$ 2,500$ per year. The following year, Year Two, after having made two premium payments, $X$ assigned the ownership of the policy to $Y$ who paid the premiums thereafter. At the time of the transfer, the cash surrender value of the policy was $\$ 300$, and $X$ 's reserve in the policy was only slightly larger. Consequently, because of the $\$ 3,000$ annual exclusion, $X$ incurred no gift tax liability. When $X$ died a little more than four years after the assignment

107. C. LOWNDES, R. KRAMER \& J. MCCORD, supra note 27 , at $\$ 13.4$, at 327-28.

108. See Treas. Reg. \$§ 20.2042-1(a)(2), .2039-1(d) (1958).

109. C. LOWNDES, R. KRAMER \& J. MCCORD, supra note 27 , at $\S 13.4$, at 328. 
was effected, $Y$ had made four premium payments. $Y$ then collected the $\$ 100,000$ insurance proceeds. Under section $2042(2)$, no part of the proceeds is included in $X$ 's gross estate. But if the premium payment test were in force, one-third of the proceeds (approximately $\$ 33,000$ ) would be included in $X$ 's gross estate.

What connection is there between the two premium payments made by $X$ and the collection of the insurance proceeds? Each premium payment made by $X$ purchased both risk insurance coverage for the year involved and an equity interest. The equity interest (some $\$ 300$ ) that was given to $Y$ when the policy was assigned should not be included in $X$ 's gross estate. In this respect the premium payment test is topsy-turvey in effect, in that the greater the number of premiums paid by the insured, the greater the amount of reserve in the policy that should be excluded from his gross estate; yet under the premium payment test, each payment made by the insured prior to the assignment will increase the amount included in his gross estate. The risk coverage that $X$ acquired was for a one-year period only and thus expired at the end of Year Two. From whence, then, is the remaining $\$ 99,700$ of insurance proceeds derived? A relatively small portion of it (some several thousand dollars) is attributable to the portion of the premiums paid by $Y$ which were allocated to $Y^{\prime}$ 's equity interest (reserve), and surely no part of $Y$ 's premium payment should be included in $X$ 's gross estate. Thus, an amount equal to the reserve in the policy as of $X$ 's death should be excluded. The remainder of the proceeds (some $\$ 95,000$ ) is attributable to the risk insurance coverage purchased with the remaining portion of the preinium paid by $Y$ for the year in which $X$ died. There is no justification for taxing the proceeds of risk coverage in the gross estate of $X$ if the coverage was acquired by $Y$.

But $X$ did give $Y$ something more than the equity reserve component of the policy in Year Two. $X$ also gave $Y$ the term insurance coverage component for the remainder of Year Two, and the right of continuation component (the right to purchase risk coverage on $X$ 's life at a contractually fixed price for years following Year Two). If $X$ were in good health at the time, the assignment of the right of continuation component would have no value since anyone with an insurable interest could purchase risk coverage on $X$ 's life for a premium of equal amount. If, however, $X$ were in poor health at that time, the right to purchase risk coverage at a price set for a healthy insured would be of tangible value to $Y$. This extra benefit perhaps should affect the valuation of $X$ 's gift for gift tax purposes. ${ }^{110}$ So, also, should the transfer of the term insurance coverage component for the

110. Under current practice, however, the gift tax valuation is made without regard to the actual health of the insured. See generally Treas. Reg. $\$ 25.2512-6$ (1958). In a comparable situation, it has been held by several courts and the Service that in determining the value of 
remaining part of Year Two itself. But neither of these should alter the estate tax consequences since any extra benefit assigned by $X$ was given away more than three years prior to his death.

It might be contended that the premium payment test is a rough means of compensating the government for not taking the insured's health into account in valuing the policy for gift tax purposes at the time it was assigned. The test fails to qualify as a reasonable adjustment to compensate for lost gift taxes for two reasons. First, there is an inverse relationship between the number of premiums paid by the insured and the amount of insurance protection assigned, and second, the number of premium payments made prior to the assignment does not bear even a remote relationship to the health of the insured, whose health controls the value of the right to continue the insurance coverage.

As a second example, assume that in Year One, $H$ took out a $\$ 100,000$ policy insuring his wife, $W$, who was the primary earner of the family. $H$ named himself as beneficiary of the policy. $H$ had an insurable interest in $W . H$ paid all premiums on the policy for five years and then $W$ died. None of the proceeds are included in W's gross estate, and even the premium payment test would not cause the inclusion of any of the proceeds. If, instead, $W$ had taken out the policy in Year One and paid one premium, then assigned the policy to $H$ six months later and died five years after that, no justification exists for taxing a portion of the proceeds in W's gross estate. In both situations, the insurance proceeds are largely attributable to the risk coverage purchased under the policy and it is W's death which causes the policy to mature; the fact that in one situation $W$ paid one year's premium and did not do so in the other does not warrant different estate tax consequences.

In Silverman, the Tax Court excluded 11.29 percent of the proceeds from the insured's gross estate because that percentage of the premiums had been paid by the assignee. ${ }^{111}$ No more rationality can be found in that apportionment than existed in the premium payment test which Congress rejected in 1954. Withm three years of his death, the insured assigned a straight life policy which had a value that was at least equal to his equity

insurance policies owned by a husband and wife on the lives of each other, who die in a common disaster, the imminence of each insured's death immediately prior to the death of the policyholder did not affect the valuation of the policy for estate tax purposes. See Estate of Wien v. Commissioner, 441 F.2d 32 (5th Cir. 1971); Estate of Meltzer v. Commissioner, 439 F.2d 798 (4th Cir. 1971); Old Kent Bank \& Trust Co. v. United States, 430 F.2d 392 (6th Cir. 1970); Estate of Chown v. Commissioner, 428 F.2d 1395 (9th Cir. 1970); Rev. Rul. 77-181, 1977I.C.B. 272. But cf. United States v. Ryerson, 312 U.S. 260, 262 (1941) (replacement value rather than cash-surrender value considered best criterion of value, since the decedent may have in the interim become uninsurable). The justification for not taking the insured's health into account is discussed in the text accompanying notes 117-20.

111. 61 T.C. at 342 . 
reserve, and surely no portion of that reserve should have been excluded from his gross estate. The percentage of premiums paid by the assignee has no relevance to the determination of the value of the interest transferred by the insured. The failing of the Tax Court's formula becomes readily apparent when tested by applying it to a variety of hypothetical facts. Consider, for example, the situation in which an insured became seriously ill two years after acquiring a life msurance policy and promptly assigned the policy to his brother, who paid premiums for two additional years before the insured died. It would be patently inappropriate to exclude one-half of the proceeds from the insured's gross estate, since the insured transferred a policy worth much more than half its face value at the time of transfer.

3. The Proposed Treatment. If the Tax Court's formula is unrealistic, how should the Silverman situation have been resolved? As noted earlier in this Article, when an insured assigns away the ownership of a life insurance policy, he is making a gift of three separate economic components: the equity reserve component (his reserve in the policy), the term insurance coverage component (the pure insurance coverage for the period covered by his last premium payment), and the right of continuation component (the continuing right to purchase that coverage at a fixed price for subsequent periods). To determine the proper treatment for the assignee's premium payments, it is helpful to examine these components separately and to consider the extent to which any increase in their value between the assignment and the date of the insured's death would be includable in the insured's gross estate under a normal application of the principles of section 2035.

(a) The equity reserve component. The first property interest, the amount of the insured's reserve in the policy at the date of assigninent, should be included in his gross estate as a transfer made withm three years of death. The size of the reserve will be greater at the date of the insured's death than at the time of the gift because of two independent factors: first, the reserve will increase at periodic intervals according to a rate of increase established in the insurance contract (hereinafter called the "automatic incremental increase" to the reserve); second, the reserve will be increased by the portion of the assignee's premium payments that are allocated to the policy's reserve plus any automatic incremental increase to that portion of the reserve. Clearly, the addition to the reserve caused by the assignee's premium payments and any automatic incremental increase to such additions made by the donee should be excluded from the insured's gross estate. ${ }^{112}$

112. See Treas. Reg. § 20.2035-1(e) (1958). 
The automatic incremental increase to the reserve which the insured had at the time of the transfer raises a more troublesome question. It is well settled that the post-transfer income received on property transferred within three years of death is not captured by section 2035 for inclusion in the donor's gross estate. ${ }^{113}$ An argument could be made for the application of this rule to the situation under discussion, since the automatic incremental increase to the insured's reserve bears considerable similarity to interest income. However, it is significant that such incremental increases have not been treated as realized income for income tax purposes. The reason that such incremental increases are not included in a policyholder's gross income is because the increases are not realized for income tax purposes (that is, the incremental increase has not been severed from the policyholder's equity interest); the provision that the policyholder can obtain the incremental increase only by surrendering the policy constitutes such a substantial restriction as to preclude the application of the "constructive receipt" doctrine. ${ }^{114}$ The characterization of such incremental increases need not be the same for estate tax purposes as it is for income tax purposes, but no particular reason would seem to justify treating it differently in this context. In general, the application of the estate tax laws has followed the income tax concept of realization (or severance) in determining whether to include an item in a deceased's gross estate. ${ }^{115}$ The income tax law's characterization of the automatic incremental increase (as unrealized income) is on shaky ground conceptually, however, and the treatment possibly reflects a policy to favor investments in life insurance, rather than a neutral application of tax principles. Little purpose would be served by extending this conceptually suspect characterization in order to cause exclusion of an incremental increase from a decedent's gross estate, especially since the exclusion from section 2035 of post-donation income itself has no conceptual justification and is attributable to several ill-reasoned decisions which became calcified pillars of the tax law through the application of the doctrine of precedent.

113. Id. 'See also Commissioner v. Gidwitz' Estate, 196 F.2d 813, 817-18 (7th Cir. 1952); Estate of James E. Frizzell, 9 T.C. 979, 986-90 (1947), aff'd sub nom. Burns v. Commissioner, 177 F.2d 739, 741 (5th Cir. 1949), acq. 1966-1 C.B. 2.

114. See Theodore H. Cohen, 39 T.C. 1055, 1062-63 (1963).

115. See, e.g., Harvey v. United States, 185 F.2d 463, $465-67$ (7th Cir. 1950); Swartz v. United States, 182 F. Supp. 540 (D. Mass. 1960). These cases hold that the gain recognized by a donee on the sale of an asset which had been acquired as a gift from another constitutes income to the donee from the donated property to the extent that the appreciation occurred after the donee acquired the asset; therefore, when the "income" was used by the donee as partial consideration for the acquisition of property in joint tenancy with the original donor, her use of the "income" was treated as a "contribution" by the donee to the joint tenancy for purposes of the percentage of consideration rule applied by section 2040 . If the donee had not sold the appreciated property she had been given by the donor, but instead had contributed it to the purchase of property held in joint tenancy with the donor, the donee's contribution (including the appreciated element of her contributed property) would be credited to the donor for 
Accordingly, the insured's gross estate should include the value of the policy's equity reserve component ${ }^{116}$ at the date of his death less any portion of the equity reserve component that was derived from the assignee's premium payments.

(b) The term insurance coverage and the right of continuation components. An insured's assignment of a policy also constitutes a gift of the term insurance coverage and the right of continuation components. The value of these components at the time of assignment is at least equal to the portion of the premium previously paid by the insured which is attributable to the remainder of the period for which that premium was paid. Thus, if the insured paid a premium of $\$ 1,200$ on March 1 , for term insurance coverage for one year, and the insured assigned the policy to his wife three months later (on June 1), he would have made a gift having a value of at least $\$ 900$ $(3 / 4$ of $\$ 1,200)$. If the insured is in good health, the above-described allocation of the premium will accurately reflect the value of both components. The amount of each premium will equal the value of the risk coverage involved; the premium will have been set according to an actuarial determination of the risk assumed by the insurer, including the granting to the policyholder of an option to contimue that insurance coverage in future years at a cost designed for healthy persons. Stating it differently, if the assignee has an insurable interest in the insured, the assignee could purchase the same amount of insurance coverage at the same price, and the value of the right of continuation component is zero. However, if the insured is in poor health at the time of the assignment, the premium payable for the term insurance coverage will be less than the actual value of such insurance coverage; consequently, the value of the insurance granted to the assignee (both the coverage for the remainder of the period and the option to continue the coverage at a bargain price) will exceed the premium allocation described above.

If the insured's ill health were taken into account in valuing an assigned policy for gift tax purposes, it would be necessary to determine the health of the insured in the case of each such assignment, and to estimate the effect of the insured's health on the valuation question by resorting to medical evidence and actuarial expertise. Such inquiries would impose a great administrative burden on both the government and on taxpayers. Presum-

purposes of section 2040. See Treas. Reg. $\$ 20.2040-1$ (c), Exs. (4) \& (5) (1958). The severance of the appreciation from the donated property caused it to be treated as the donee's income for estate tax purposes, and it will not be so treated if it is not severed. Rev. Rul. 55-379, 1955-1 C.B. 449.

116. Even if it were decided that the automatic incremental increase of the insured's reserve should be excluded, that will be a relatively small figure since the period involved cannot exceed three years. 
ably because that burden would be too costly, the Service has not taken the insured's health into account in valuing policies for gift tax purposes (or where a decedent died owning a policy on the life of another person and the policy must then be valued for estate tax purposes). ${ }^{117}$

A similar question, involving the value at the date of gift of a donated life insurance policy, arose in Estate of James Stuart Pritchard. ${ }^{118}$ In that case, the insured, after having undergone several operations for cancer, "sold" a $\$ 50,000$ face amount life insurance policy to his wife for approximately $\$ 10,000$ - the cash surrender value of the policy. The insured died thirty days later. The court held that the $\$ 10,000$ payment did not constitute adequate and full consideration for the policy, which had a value far in excess of its cash surrender value due to the insured's poor health. Accordingly, the court held that the policy was transferred in contemplation of death. ${ }^{119}$ The court answered the taxpayer's contention that it would be administratively impractical to approximate the actual life expectancy of each donor of life insurance by pointing out that it was not necessary in that case for the court to determine the actual value of the donated policy. The court had to determine no more than that the policy's value was greater than $\$ 10,000$ to find that the consideration was inadequate. The case does not deal with the question of whether the policy should have been valued for gift tax purposes by taking the insured's illness into account, and the court expressly declined to determine that value.

After the 1976 Act's adoption of an automatic rule of inclusion for gifts made within three years of deatl and its integration of estate and gift tax rates, there is particularly good reason not to consider the health of the insured in valuing donated policies. If the insured's health were taken into account, it is likely, because of administrative difficulties, that the government would raise the issue only if the insured died slortly after making the gift; in most such events the proceeds will be captured in the insured's gross estate under section 2035. The principal revenue loss in not valuing a donated policy in light of the insured's health is therefore a few years' deferral of the transfer tax on any added value caused by the insured's poor health, and that brief deferral will not likely justify the enormous administrative burden of attempting to determine the insured's actual life expectancy.

For purposes of section 2035, the value of the term insurance coverage

117. See note 110 supra.

118. 4 T.C. 204 (1944).

119. Had the taxpayer been able to show that the transfer was for adequate and full consideration, the policies would not have been included in the insured's gross estate as transfers in contemplation of death, by virtue of Int. Rev. Code of 1939, ch. 3, §811(c), 53 Stat. 121 (now I.R.C. \& 2035(b)(1)). 
and the right of continuation component at the time of assignment is not paramount. It is the value of these components at the time of the transferor's death that controls. At that date, of course, the value of the term insurance coverage component is zero, since by definition the insured has outlived the period covered by the last premium he paid. The difference between the face amount of the insurance (that is, the proceeds payable on the insured's death) and the policy's reserve is attributable partly to the right of continuation component that the insured transferred to the donee and partly to the donee's having paid the subsequent premiums as they come due. The proceeds, however, would not have been payable if the premiums had not been paid, and so account must be given to the assignee's payment of those premiums. Rather than treating each premium payment as the purchase of an independent asset (risk coverage for a stated term), it is more accurate to characterize such payments as a maintenance expense of the right of continuation component. The insurance coverage element of a policy should therefore be treated as a continuum and not as a collection of a number of contractual arrangements-one for each term of a premium payment. Indeed, it is this characterization of life insurance coverage as a continuum that justifies the inclusion in an insured's gross estate of only the amount of premiums paid by the imsured on either a straight life or a term insurance policy within three years of his death (where the policy itself had not been transferred by the insured withm three years of his death) despite the fact that the entire proceeds of an accidental death policy are included in an insured's gross estate where the insured paid the final premium thereon within the three-year period prescribed by section 2035 - that is, premiums paid on term or straight life insurance are merely maintaining continuous insurance coverage while a premium paid on an accidental death policy constitutes a de novo purchase of the insurance coverage itself. ${ }^{120}$

Treating insurance coverage as a continuum or single asset is not only a realistic view of the asset itself, it is necessary in order to accommodate the legislative purpose for adopting section 2035 and to avoid great administrative burdens. If a premium payment were treated for purposes of section 2035 as an independent purchase by the assignee of risk coverage for the stated term, it might then be necessary to exclude from the insured's gross estate the risk coverage element of the proceeds (that is, the difference between the amount of the proceeds and the reserve), since that value would then be deemed to have been added by the assignee. The purpose of section 2035 , to prevent the use of lifetime transfers as a means of minimizing transfer tax costs, would be frustrated, particularly where the insured was in poor health when he assigned the policy. This method would also overstate the amount added to the policy's value by the assignee. To prevent that

120. See Rev. Rul. 71-497, 1971-2 C.B. 329. See text accompanying notes 71-74 supra. 
frustration and overstatement, it would be necessary to value the risk coverage element of the policy at the time of assignment and then deduct that value from the risk coverage element at death to determine the amount of the proceeds that actually are attributable to the assignee's premium payment. This method would provide a more accurate reflection of the assignee's addition to the value of the policy than would the method utilizing the entire risk coverage element.

The objection to the above approach, however, is that it requires that an appraisal be made of the health of the insured at the time of assignment and that an actuarial and medical evaluation be made of his life expectancy at that time. As noted above, the difficulties in making that determination and the burden of exploring those issues led the government to value unmatured insurance policies without regard to the actual health of the insured. ${ }^{121}$ The same factors point to the treatment of life insurance coverage as a continuum in order to avoid the great difficulties of valuing the unmatured policy at the time of assignment. Indeed, the factual problems raised by requiring such a valuation of the policy at the time of assignment are reminiscent of the problems that arose in determining whether a transfer was made in contemplation of death. Congress of course replaced the "contemplation of death" test in 1976 with an automatic rule of inclusion just so that it could eliminate both the administrative burden of making inquiries of this type and the frequent factual errors made in resolving such issues. While it is true that the contemplation of death rule involved questions of subjective intent that would not be raised in examining the insured's state of health, it would still be necessary in both situations to look into the past and determine some aspect of an individual's personal state without having any access to information from the person himself.

Even if the health evaluation method were correct in theory, it would operate equitably only where the past health of the insured can be accurately determined; the great likelihood that substantial errors will be made in resolving such factual issues renders this approach undesirable. While the treatment of the assignee's payments as maintenance of the right of continuation component is somewhat draconic, it has the advantage of being doctrinally supportable, not only for the reasons discussed above, but also because such treatment is consistent with the perceptions of the usual insured and his assignee. It also avoids the burdens and risks of factual error that attend an approach which requires an evaluation of the insured's life expectancy.

Viewing the assignee's contribution as a maintenance cost, the question is whether the proceeds should be reduced by any portion thereof other

121. See Rev. Rul. 77-181, 1977-1 C.B. 272 , and text accompanying notes 117-20 supra. 
than the portion allocated to the policy's reserve. Since the insured's gross estate would have been reduced by such payments if he had retained the policy and made the premium payments (that is, the cash used to pay the insurance cost would no longer be part of the insured's assets), the assignee's payment should be treated as a contribution by him to the extent that the payment is allocated to the cost of purchasing insurance coverage (which cost includes the insurer's expenses that are passed on to its policyholders). Therefore, the amount of the portion of each premium payment that is not applied to the policy's reserve should also be deducted from the proceeds that are includible in the insured's gross estate. ${ }^{122}$

\section{CONCLUSION}

The principle issue, then, is what amount should be included in an insured's gross estate when he assigned a life insurance policy within three years of death, the post-assignment premiums on which were paid by the assignee. To arrive at the correct amount which should be included, the proceeds of the policy should first be reduced by the portion of the assignee's premium payments which are allocable to the policy's reserve and the portion allocable to insurance coverage, which two portions together constitute the entire amount of the premiums paid by the assignee. Additionally, the automatic incremental increase of the reserve added by the assignee's payments should be excluded, but this will be a relatively small amount and a burdensome figure to compute. In the interest of simplicity and administrative ease, it would be preferable to include in the insured's gross estate the entire amount of the proceeds of the policy less the aggregate amount of premiums paid by the assignee. As mentioned above, the Government noted this treatment as a possible solution in its brief on appeal in Silverman, ${ }^{123}$ but did not urge its adoption. The Second Circuit hinted that it favored this approach, but since the Government was not pressing the issue, the court refrained from passing upon it. The above approach would conform with congressional aims and provide ease of administration without straining the conceptual analysis of the transaction.

It is noteworthy that this proposed treatment is consistent with the authors' analysis of the proper estate tax treatment of an insured's assignment of a life insurance policy within three years of his death where the donee permitted the policy to lapse. ${ }^{124}$ The authors concluded that only the value of the equity reserve component, if any, of a lapsed policy should be

122. Cf. Estate of Peters v. Commissioner, 386 F.2d 404 (4th Cir. 1967) (the value of a surviving joint tenant's capital improvements are deducted from the value of jointly owned property that must be included in the decedent's gross estate under I.R.C. $\$ 2040$ ).

123. 521 F.2d at 577.

124. See text accompanying notes 87-91 supra. 
included under section 2035. The donee's payment of premiums, under the authors' analysis, does not constitute the de novo purchase of insurance coverage but rather constitutes an expense of maintaining the right of continuation component that the donee had acquired from the insured. A donee's failure to maintain a policy will cause a reduction in its value just as the donee's failure to maintain other types of donated property, such as real estate or livestock, will impair the value of the donated property.

Even if the authors' conclusion that only the equity reserve component of a lapsed policy is captured by section 2035 is not accepted, a contrary holding that the face amount of a lapsed life insurance policy is to be included in the insured's gross estate is reconcilable with the principal aspects of the authors' conclusion concerning policies which did not lapse. If the donee's failure to pay the required premiums would not affect the amount included in the insured's gross estate (contrary to the authors' conclusion), then obviously the donee's payment of such premiums should not affect the amount so included. This analysis, however, would not warrant a reduction in the insured's gross estate for the amount of premiums paid by the donee, and that fact alone appears sufficient to justify the authors' view that only the cash value of a lapsed policy is caught by section 2035. 